\title{
Depositional systems of the late Eocene Yolomécatl Formation, northwestern Oaxaca, southeastern Mexico: a first approach
}

\author{
Ismael Ferrusquía-Villafranca ${ }^{1, *}$, José Ramón Torres-Hernández ${ }^{2}$, \\ José E. Ruiz-González ${ }^{1}$, and Enrique Martínez-Hernández ${ }^{1}$ \\ ${ }^{1}$ Instituto de Geología, Universidad Nacional Autónoma de México, Circuito de la Investigación s/n, \\ Ciudad Universitaria, Coyoacán, Ciudad de México, C.P. 04510, Mexico. \\ ${ }^{2}$ Instituto de Geología, Universidad Autónoma de San Luis Potosí, Av. Dr. Manuel Nava 5, San Luis Potosí, C.P. 78000, Mexico. \\ *ismaelfv@unam.mx
}

\section{ABSTRACT}

The discrimination/characterization of depositional systems recorded in formal lithostratigraphic, Cenozoic, continental, epiclastic units of Mexico, is largely a pending task, notwithstanding its great academic and economic importance. Contributing to fill this gap, we present a first approach to discriminate and characterize the depositional systems of the late Eocene Yolomécatl Formation, which fills the namesake, triangle-shaped tectonic basin, and carries the southernmost Paleogene vertebrate fauna of North America. The study area lies between $17^{\circ} 25^{\prime}-17^{\circ} 30^{\prime}$ North Latitude and $97^{\circ} 29^{\prime}-97^{\circ} 36^{\prime}$ West Longitude, and between 2000-2500 m a.s.l.; the federal highway 125 traverses it; Santiago Yolomécatl is the main town.

The Yolomécatl Formation is at least $650 \mathrm{~m}$ thick, although the continuous thickness measured in the principal reference section is much less $(\sim 250 \mathrm{~m})$; it includes fluvial and lake depositional systems sparsely interbedded by tuff sheets (a system per se). The fluvial system consists of 1) $\mathrm{Gmm}, \mathrm{Gmg}$, Gcm lithofacies: alluvial fans and related deposits; 2) Gm, Gh, Gp, Gt, St, Sp lithofacies: channel lag deposits; 3) Sr, Sh, Sl, Fl lithofacies: floodplain deposits. The (clastic) lacustrine system includes: 1) Ll, Lsm, Lm lithofacies: offshore deposits; 2) Ll, Lsm lithofacies: playa lake and mud flats deposits. This large thickness of this unit indicates superposition of fluvial/lacustrine systems, and sparse pyroclastic emplacements that took place in a basin gradually subsiding with sedimentation, under humid to subhumid conditions, probably interrupted by seasonal dryness.

Finally, the tectonic setting of the Yolomécatl Basin, indicates that its genesis and development are related to the dynamics of the regional, left-lateral strike-slip Tamazulapam fault, which is also regarded as the boundary between the Mixteca (west) and Oaxaca (east) terranes.

Key words: Mexico; Oaxaca; Yolomécatl Formation; Eocene; depositional systems.

\section{RESUMEN}

La discriminación/caracterización de los sistemas de depósito registrados en unidades litoestratigráficas formales, cenozoicas, epiclásticas, continentales de México, es en gran parte una labor pendiente, a pesar de su enorme importancia académica y práctica.
Para contribuir a llenar este vacío, presentamos un primer acercamiento para discriminar y caracterizar los sistemas de depósito de Formación Yolomécatl del Eoceno tardío, la cual rellena totalmente la cuenca triangular homónima delimitada por fallas normales, e incluye la fauna de vertebrados más meridional de Norteamérica para esa época. El área de estudio se encuentra entre $17^{\circ} 25^{\prime}-17^{\circ} 30^{\prime}$ Latitud Norte y 97 $29^{\prime}-97^{\circ} 36^{\prime}$ Longitud Oeste, y entre 2000 y 2500 m s.n.m.; la carretera federal 125 atraviesa la cuenca, y Santiago Yolomécatl es el poblado principal.

Se estima que la Formación Yolomécatl tiene un espesor mínimo de $650 \mathrm{~m}$, aunque el espesor contínuo medido es mucho menor ( 250 $m$ ); esta formación incluye sistemas fluviales y lacustres intercalados con depósitos piroclásticos (un sistema por sí mismo). El sistema fluvial consiste de: 1) las litofacies $\mathrm{Gmm}, \mathrm{Gmg}$, Gcm: abanicos aluviales y depósitos relacionados; 2) las litofacies $G m, G h, G p, G t, S t, S p$ : depósitos de arrastre en canal; 3) las litofacies Sr, Sl, Sh, Fl: depósitos de planicie de inundación. El sistema lacustre (clástico) incluye: 1) las litofacies Ll, Lsm, Lm: depósitos lago adentro; 2) las litofacies Ll, Lsm: depósitos de ribera. El gran espesor de esta unidad indica sobreposición de los sistemas fluvial/ lacustre y la intercalación espaciada de piroclásticos en una cuenca que se hundía gradualmente con la sedimentación, bajo condiciones subhúmedas, interrumpidas por otras de aridez, tal vez estacional.

Finalmente, el marco tectónico de la Cuenca Yolomécatl, indica que su origen y desarrollo están relacionados con la dinámica de la falla regional sinistral Tamazulapam, la cual también se considera como la frontera entre los terrenos Mixteca, al oeste y Oaxaca, al este.

Palabras clave: México; Oaxaca; Formación Yolomécatl; Eoceno; sistemas de depósito.

\section{INTRODUCTION}

After $\sim 130$ years of geologic research in Mexico, important tasks have been barely touched, such as the discrimination and characterization of depositional systems registered in formal, continental, epiclastic, Cenozoic lithostratigraphic units of this country, in spite of their academic and economic importance. Only a few papers on this subject have been published (e.g. Chávez-Cabello et al., 2007; Ferrusquía-Villafranca and Ruiz-González, 2011; FerrusquíaVillafranca et al., 2016a; Puy-Alquiza et al., 2017). Regarding the 
academic importance, it allows to unravel the sedimentary architecture of the basin fill, which influences the flow and 'emplacement' of ground water, hydrocarbons, and/or mineralizing fluids. The characterization of the basin, ultimately, permits to delineate its genesis and evolution within its regional tectonic setting; in addition, such studies help to disclose the climate regime and geologic/geomorphic setting encountered by the biota that lived there at the time of deposition, as well as to confidently infer the geology of the source area. As for the economic importance, it is critical to explore for groundwater, hydrocarbons, and placer deposits.

As a contribution to continue filling this gap, we present here the results of the research Project IN-110614, entitled "Estudio geológicogeofísico, tectono-sedimentario biótico y paleoambiental del Terciario continental de la Cuenca Yolomécatl-Tlaxiaco, Oaxaca occidental: Implicaciones en el entendimiento de la evolución cenozoica del Sureste". This is our first approach to broadly discriminate the depositional systems of the late Eocene Yolomécatl Formation, northwestern Oaxaca (Ferrusquía-Villafranca et al., 2016b); thus, a finer discrimination and mapping out the lithosfacies is left out for a future study.

The Yolomécatl Formation is important on these accounts: a) Geology: It occupies a basin sited in an area tectonically influenced by the dynamics of the Tamazulapam fault, a major left-lateral, strike-slip fault of the Mixteca Region, also regarded as the boundary between the Mixteca and the Oaxaca terranes. This major structure influenced deposition and emplacement of Paleogene sedimentary and magmatic units; further, very few basins with a like tectonic setting have been described in México, e.g. the Ixtapa Basin, Chiapas (Ferrusquía-Villafranca, 1996; Mandujano-Velázquez and Keppie, 2009), and the Chihuahua Trough (Haenggi, 2002). b) Paleontology: It bears the southernmost Paleogene vertebrate fauna of North America (Jiménez-Hidalgo et al., 2015), which is fairly diverse and occupied a tropical/subtropical environment (as disclosed by the fauna and flora recovered from this unit). This biota stands in strong contrast with the numerous and well known temperate Paleogene faunas of the United States and southern Canada. All these facts render very significant the geologic information on this area both locally and regionally; thus, it could be interesting for both sedimentary geologists, particularly those working on basin analysis, and vertebrate paleontologists.

\section{Geographic setting}

The study area (Figure 1) lies between $17^{\circ} 25^{\prime}-17^{\circ} 30^{\prime}$ North Latitude and $97^{\circ} 29^{\prime}-97^{\circ} 36^{\prime}$ West Longitude, and $2200-2500 \mathrm{~m}$ a.s.l. It comprises a $\sim 90 \mathrm{~km}^{2}$ surface of rugged relief; the main currents that drain it are the ríos Teposcolula, Yodonda and Mixteco/Negro, all draining to the north. Most of the area is high ground, covered by forest; the western fourth is relatively lower, less forested and partly used as plow fields; it also includes a belt of badlands (in the central-west part). The area is well populated (INEGI, 1984), and includes the Santiago Yolomécatl town, and the villages, from north to south: San Miguel Tiza, Ixtapa, Tecolotitlán, Santa Catarina, Santo Domingo Ticú, and San José de Gracia. The federal highway 125 traverses the area joining Tiza, Ixtapa and Yolomécatl, continuing further southwesternly to Tlaxiaco. The villages are largely connected by unpaved roads.

\section{Geologic setting}

The following synopsis largely draws from Ferrusquía-Villafranca et al. (2016b). In this area, rock units of late Jurassic to Quaternary ages are exposed (Figures 2-3). The Late Jurassic San Juan Limestone barely reaches the area: it is a sequence of dark gray to black, well indurated, partly dolomitized, largely pelmicritic limestone set in medium to thick strata. The Albian-early Coniacian Teposcolula Limestone unconformably overlies San Juan Limestone; it consists of biomicritic

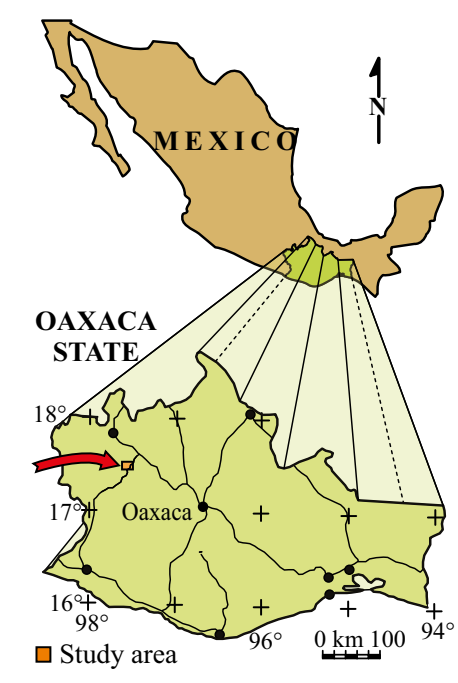

$\begin{array}{llllllllllllllll}\text { L } & \mathbf{E} & \mathbf{G} & \mathbf{E} & \mathbf{N} & \mathbf{D}\end{array}$

- Town and villages

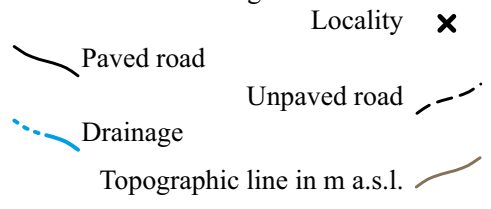

Topographic line in $\mathrm{m}$ a.s.1.

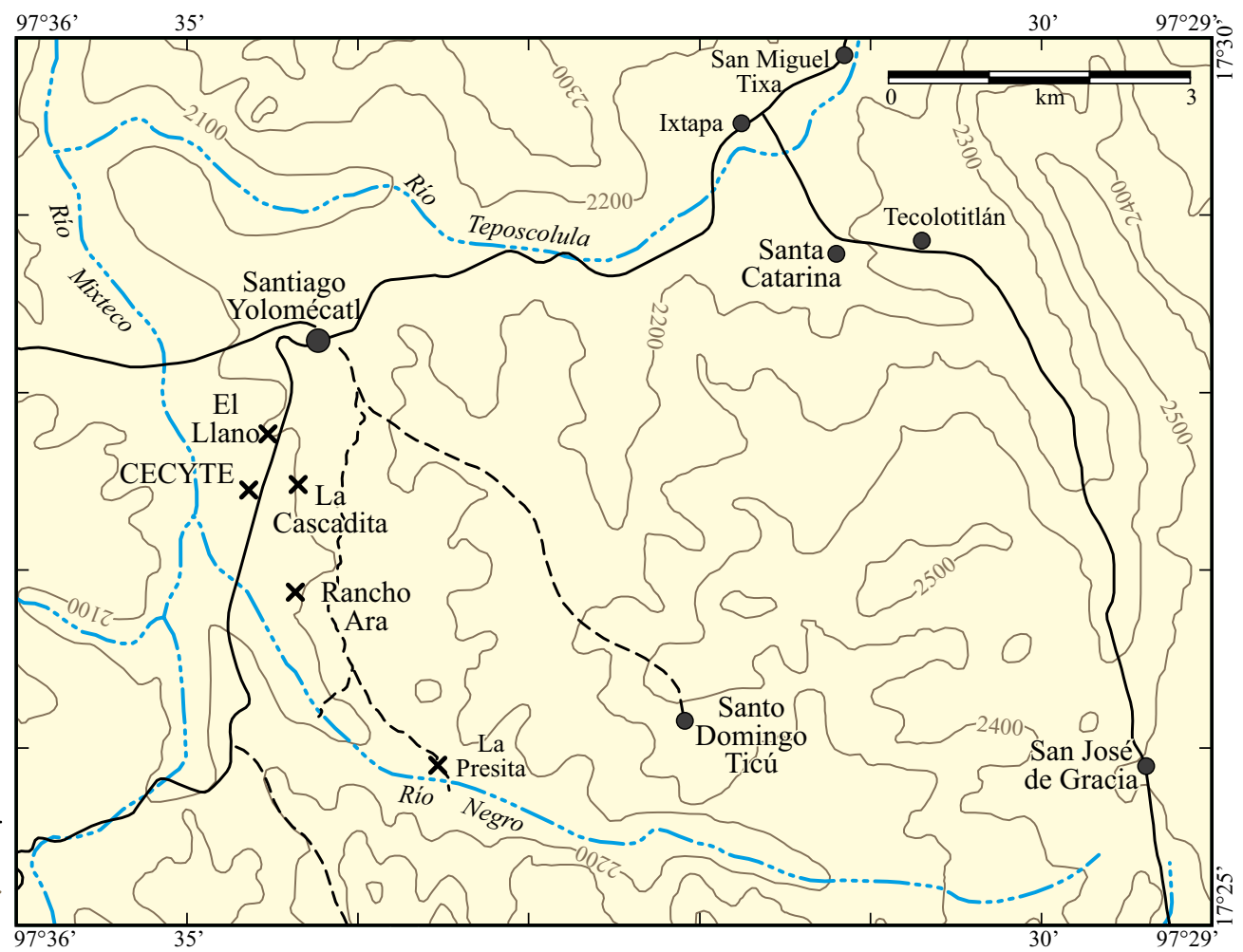

Figure 1. Index map of Oaxaca showing the location of the Yolomécatl area, northwestern Oaxaca, Mexico (pointed by the arrow), as well as the villages, rivers and sites mentioned in the text. 
and pelmicritic limestone set in thick strata, which are strongly faulted and folded into N-S trending anticlines and synclines forming a massif/range bound to the west by the left-lateral Tamazulapam fault. A small Teposcolula Limestone tectonic scale detached from the massif, and thrusted over the Nduayaco Group (see below), is also present (Figure 2).

The Cenozoic sequence includes the late middle Eocene (pre- 40.3 Ma) Nduayaco Group [in the sense of the NACSN (2005), Art. 28, Remark (a)], which is a volcanic succession that extensively crops out in the area, forming partly peneplained hills and small cuestas; it mainly consists of basaltic andesite and other intermediate to mafic flows, autobreccias, a few avalanche deposits, and subordinate amounts of ash flow tuff sheets; it is in fault contact with the Teposcolula Limestone, and unconformably underlies the Yolomécatl Formation, with which is also in fault contact. The latter formation lies in a small $\left(\sim 40 \mathrm{~km}^{2}\right.$ surface), fault-bound depression here designated Yolomécatl tectonic basin, which is genetically related to the activity of the left lateral, strike-slip Tamazulapam fault, making the basin analogous to the much larger Ridge Basin (Crowell, 2003a, 2003b). This formation is a pinkish red, continental sequence $\sim 650 \mathrm{~m}$ thick; however, we could measure only $\sim 250 \mathrm{~m}$ of continuosly exposed thickness [see Figures 4 and 5, stratotype and principal reference section], because the overall uniformity of this sequence, local faulting, lack of bed markers, and of suitable outcrops, prevented us from objectively tracing any given bed or stratigraphic level along the outcrop area of this formation, which forms a badlands belt.

The Yolomécatl Formation chiefly consists of friable to moderately indurated, largely fine-grained quartzitic-volcanic arenite, fine-grained sandstone, clayey siltstone of similar composition, and silty smectite claystone set in medium to very thick (up to $5 \mathrm{~m}$ ) strata (Tables 1, 2, and Figures 4 and 5). Interbeds include: 1) Sparse, thin to medium thick, pale brown tuff sheets of intermediate to felsic composition; one of these yielded a ${ }^{40} \mathrm{Ar}-{ }^{39} \mathrm{Ar}$ age of $40.3 \pm 1.0 \mathrm{Ma}$ datum (FerrusquíaVillafranca et al., 2016b), that places this unit and its biota in the early late Eocene. 2) Clast- to matrix-supported, boulder bearing, pebble to cobble volcanic conglomerate set in medium to thick strata, forming tongues, lenses and continuous beds, mostly in the eastern part of the Yolomécatl Formation outcrop area; their clast composition is the same as that of the Nduayaco Group flows, a fact that indicates provenance from such group. 3) Medium to thick beds of milky white to brown chalcedony or opal, an enigmatic rock formed by amorphous silica, interpreted as a heavily altered tuff. 4) Up to $2 \mathrm{~m}$ thick paleosols are present at various levels, they usually carry fungal palynomorphs (see the Supplementary Material). The lower contact of this unit does
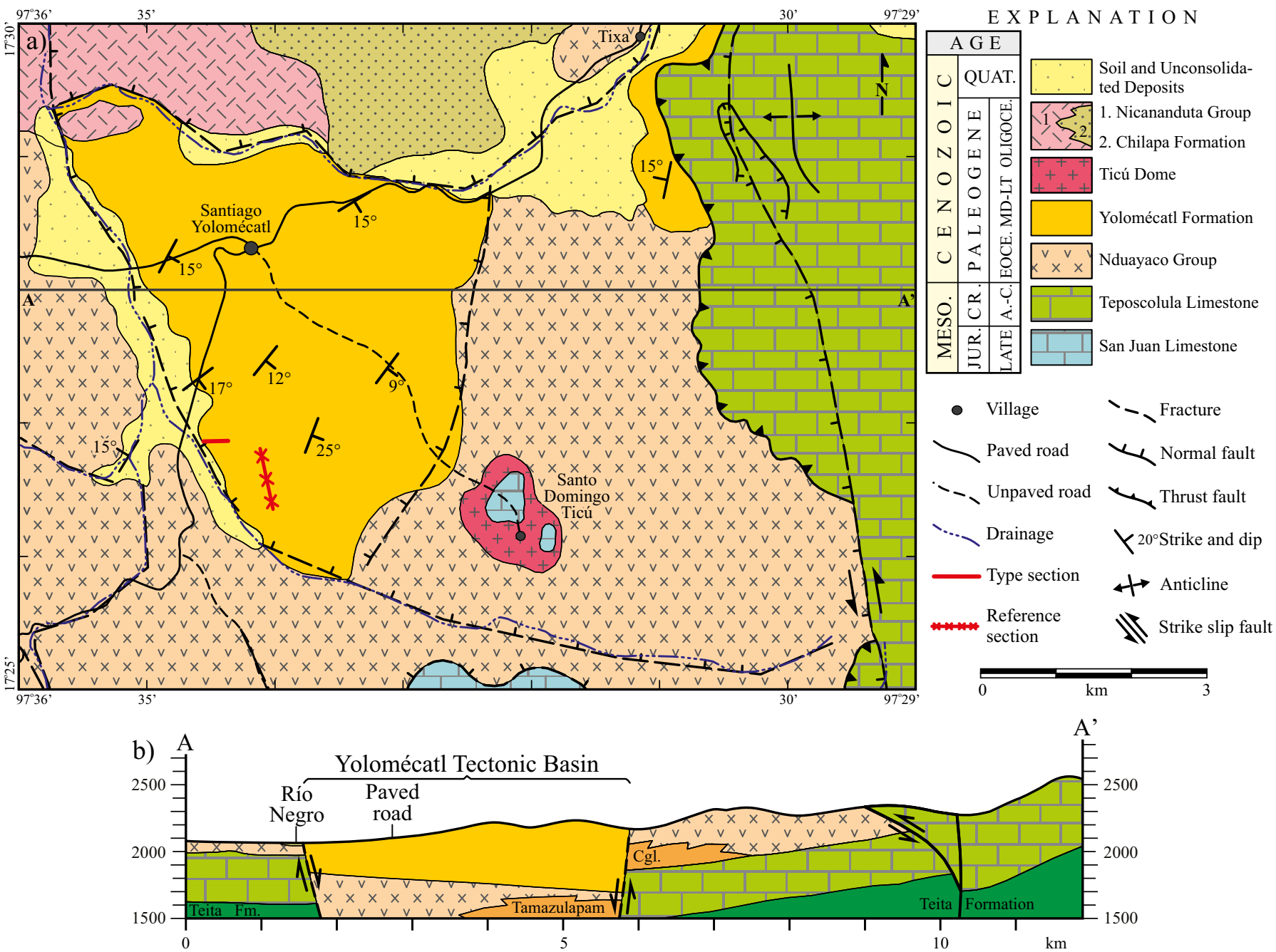

Figure 2. a) Geologic map and b) Structural section of the Yolomécatl area, northwestern Oaxaca, Mexico. Notice that the Yolomécatl Formation is preserved in the namesake tectonic basin. 


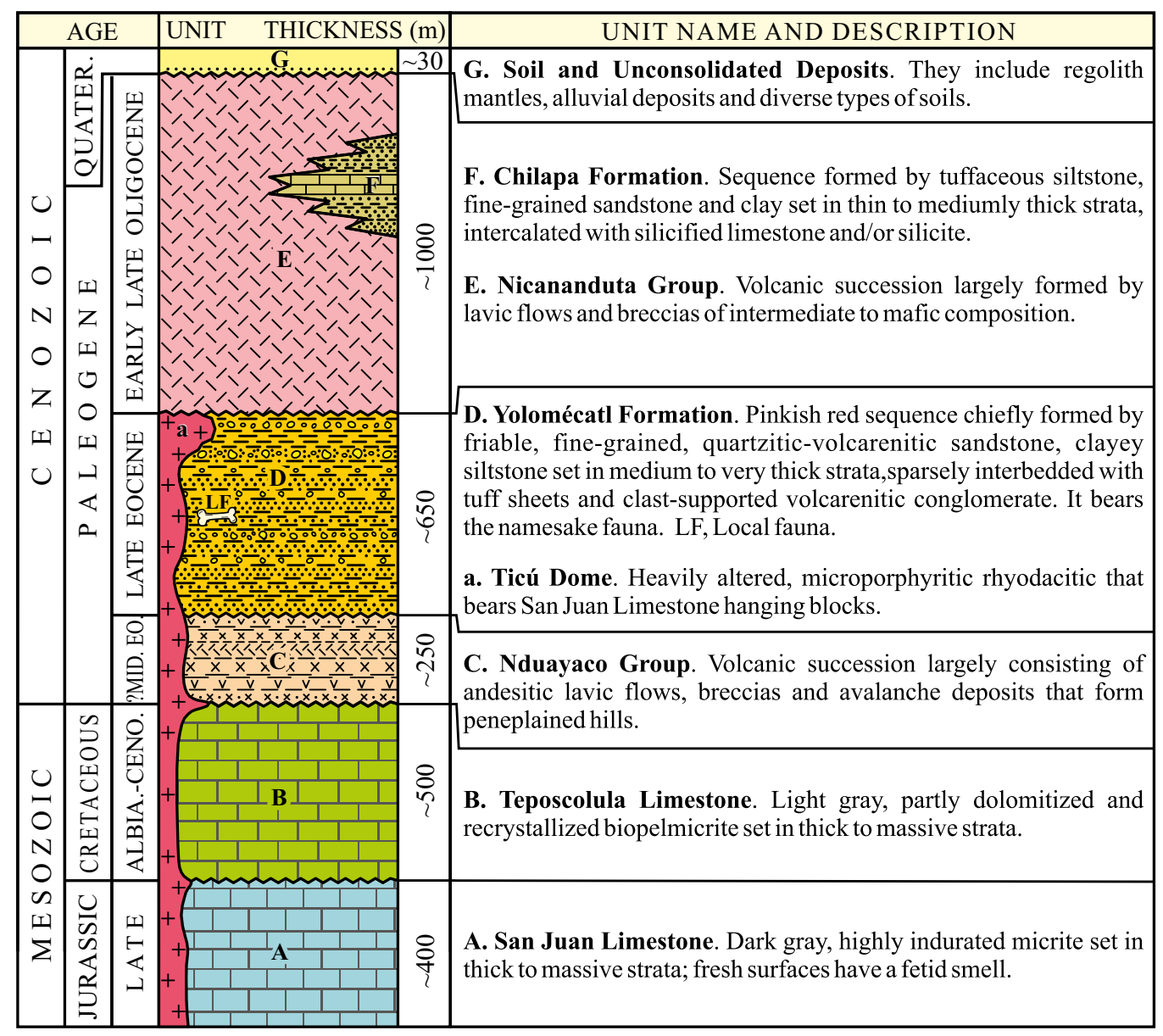

Figure 3. Generalized lithostratigraphic column of the Yolomécatl area, northwestern Oaxaca, Mexico.

not crop out; the upper contact is unconformable with the Chilapa Formation and the Nicananduta Group; it also bears the southernmost Paleogene vertebrate fauna of North America.

The Ticú dome is a small, oval, hypabyssal, dome-like rock body that lies in and around Santo Domingo Ticú. The rock is heavily altered to pinkish powdery matrix with rock fragments/remnants irregularly positioned; the less altered ones show an intermediate (dacitic) composition, which suggests some affinity with the early Oligocene, felsic Nundichi Group (a lithostratigraphic unit that crops outside but close to this area). If so, the Ticú dome would have been emplaced after the Yolomécatl deposition and before the Nundichi emplacement. Some large, altered blocks of the San Juan Limestone crop out over the dome, indicating that such unit was the host rock body, or at least part of it.

The late Oligocene $27.7 \pm 0.7 \mathrm{Ma}$ old Nicananduta Group $\left({ }^{40} \mathrm{Ar}-{ }^{39} \mathrm{Ar}\right.$ method, Ferrusquía-Villafranca et al., 2016b) is a thick volcanic succession of lava flows and autobreccias of (largely) andesitic composition and varied texture that makes up steep-slope sierras; outside but close to the area, it unconformably overlies the early Oligocene Nundichi Group which in turn overlies the Yolomécatl Formation. In the northwestern part of the area, a small part of the Nicananduta Group unconformably rests on the Yolomécatl Formation. This group also seems to intertongue the late Oligocene Chilapa Formation, a tuffaceous, stratiform rock body intercalated with lacustrine limestone strata, thus resembling the Chilapa Formation. This unit was described in the northernly adjacent Tamazulapam-Teposcolula-Yanhuitlán area (Ferrusquía-Villafranca, 1976), and as such it is cautiously regarded here; then, the Nicananduta Group and the Chilapa Formation are partly contemporaneous.

Quaternary alluvial deposits in the area lie in the valley of río Teposcolula (northeast of Yolomécatl), and in the western plain of río Mixteco; soils and plow fields are found in these sediments. Regolith mantles developed over all kinds of units, the easier ones to observe are those of unforested areas. We did not discriminate them though, to avoid clouding/crowding the map.

\section{MATERIAL AND METHODS}

\section{Cartographic material}

Map used in this study were scale 1:50000 and included: (a) Carta Topográfica Yolomécatl E14D35 (INEGI, 1984) and (b) Geologic map of the Yolomécatl-Tlaxiaco area (Ferrusquía-Villafranca et al., 2016b). The software Google Earth Pro for cartographic analyses at various scales was also used.

\section{Methodology}

The geologic work was done following standard procedures applied to discriminating and describing fluvial and lake deposits (Talbot and Allen, 1996, p. 83-92; Miall, 2006, p. 162-352). Field work was conducted during 2014, 2015 (two weeks each), and 2016 (four weeks); it consisted of walking along and describing the outcrops of all roads and trails that showed the Yolomécatl Formation (Figures 1 


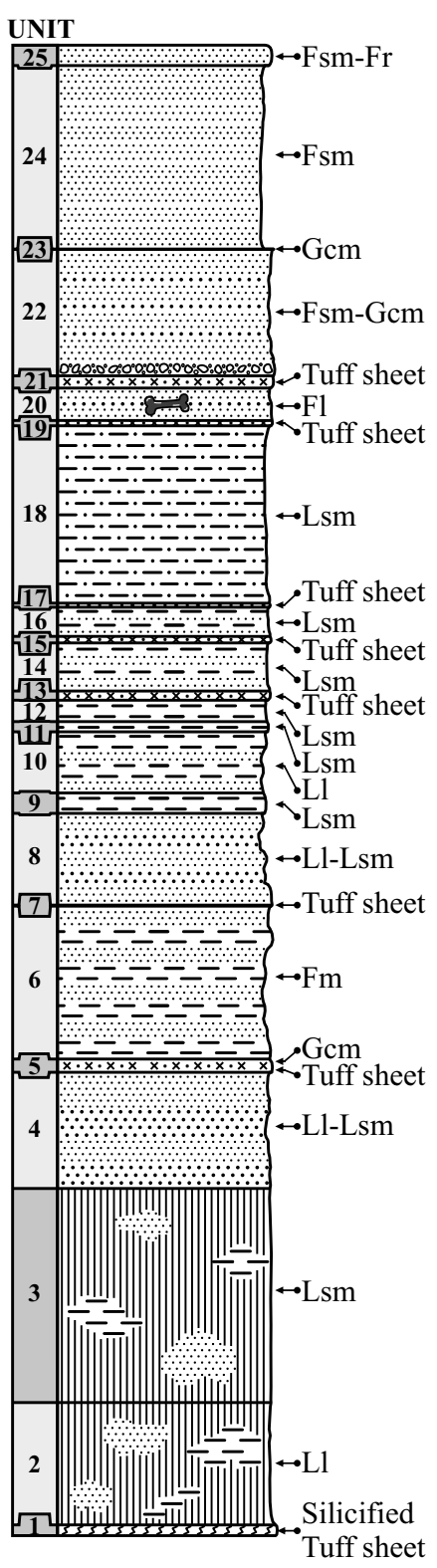

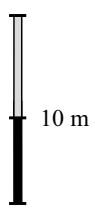

\begin{tabular}{|c|l|l|}
\hline $\begin{array}{c}\text { FACIES } \\
\text { CODE }\end{array}$ & \multicolumn{1}{|c|}{ FACIES } & \multicolumn{1}{|c|}{$\begin{array}{c}\text { SEDIMENTARY } \\
\text { STRUCTURES }\end{array}$} \\
\hline Gcm & Clast-supported massive gravel & - \\
\hline Fl & Sand, silt, mud & $\begin{array}{l}\text { Laminated sandstone, } \\
\text { siltstone and mudstone }\end{array}$ \\
\hline Fsm & Silt, mud & $\begin{array}{l}\text { Massive siltstone and } \\
\text { mudstone }\end{array}$ \\
\hline Fm & Mud, clay & Massive claystone \\
\hline Fr & Mud, silt & Massive, roots \\
\hline Ll & Sand, silt, mud & $\begin{array}{l}\text { Laminated sandstone, } \\
\text { siltstone and mudstone }\end{array}$ \\
\hline Lsm & Silt, mud & $\begin{array}{l}\text { Massive siltstone and } \\
\text { mudstone }\end{array}$ \\
\hline
\end{tabular}

Covered interval
Figure 4. Schematic representation of the Yolomécatl Formation stratotype, northwestern Oaxaca, Mexico, slightly modified to include the fluvial (Miall, 2006) and lacustrine lithofacies (this work) codes. The latter was generated following Miall's (2006) criteria. The small, punctuated areas indicate isolated outcrops within the given interval. and 2). This work included to take detailed photographs of the outcrops, tracing profiles, investigating binding surfaces, traversing the outcrops to recognize and describe lithofacies, recording of structural data, and make preliminary integrations to detect/interprete lake and fluvial sedimentary patterns. Positioning was done with a GPS equipment, and measurements with a $50 \mathrm{~m}$ steel tape. Cartographic plotting was done directly on topographic or geologic maps. The sedimentary petrographic nomenclature is largely that of Folk (1974) and Boggs (2003); the pyroclastic terminology is that of Schmid (1981), Fisher and Schmincke (1984; Branney and Kokelaar (2002), Sulpizio et al. (2014).

Fluvial facies recognition and description follows Miall (2006). Depositional systems attributes were described largely after Collinson (1996), Miall (2006, 2010), and Talbot and Allen (1996). The fluvial architectural elements and lithofacies used in this study are: $\mathrm{CH}$, Channel; LA, Lateral accretion; GB, Gravel bar and bed form; and DA, downstream accretion elements, as well as these lithofacies: $\mathrm{Gmm}$, Gmg, Gcm (alluvial and related deposits); Gm, Gh, Gp, Gt, Sp (channel deposits); Sr, Sl, Sh, and Fl (floodplain deposits) FF (overbank fines deposit) (acronyms explanation in Figures 4 and 5). Although Tha et al. (2015) proposed a lithofacies code for lacustrine clastic facies, based on Miall (2006) fluvial lithofacies code, they used the same acronym (e.g. Fl, Lsm and so on), for both fluvial and lacustrine lithofacies, which leads to confusion. To avoid it, we replaced the F for an L (lacustrine), and keep the lower case letters (which refer to the lithofacies main textural attributes), as shown here: Ll (lacustrine, laminated finegrained sandstone, siltstone and mudstone: Lsm (lacustrine siltstone and mudstone), and Lm (mud and clay): offshore lithofacies; Ll and Lsm (as above): playa lake and mud flats deposits.

Bed thickness was described following Ingram (1954). The palynologic analysis was performed using standard techniques (Batten, 1999). Depositional systems modeling was done integrating all pertinent information, i.e. recognition and discrimination of depositional systems and their lithofacies, location, description and photographic illustration of specific outcrops, plotting spatial association of similar systems and/or lithofacies on a topographic base map, and filling of gaps assuming continuation of nearest features/data. 

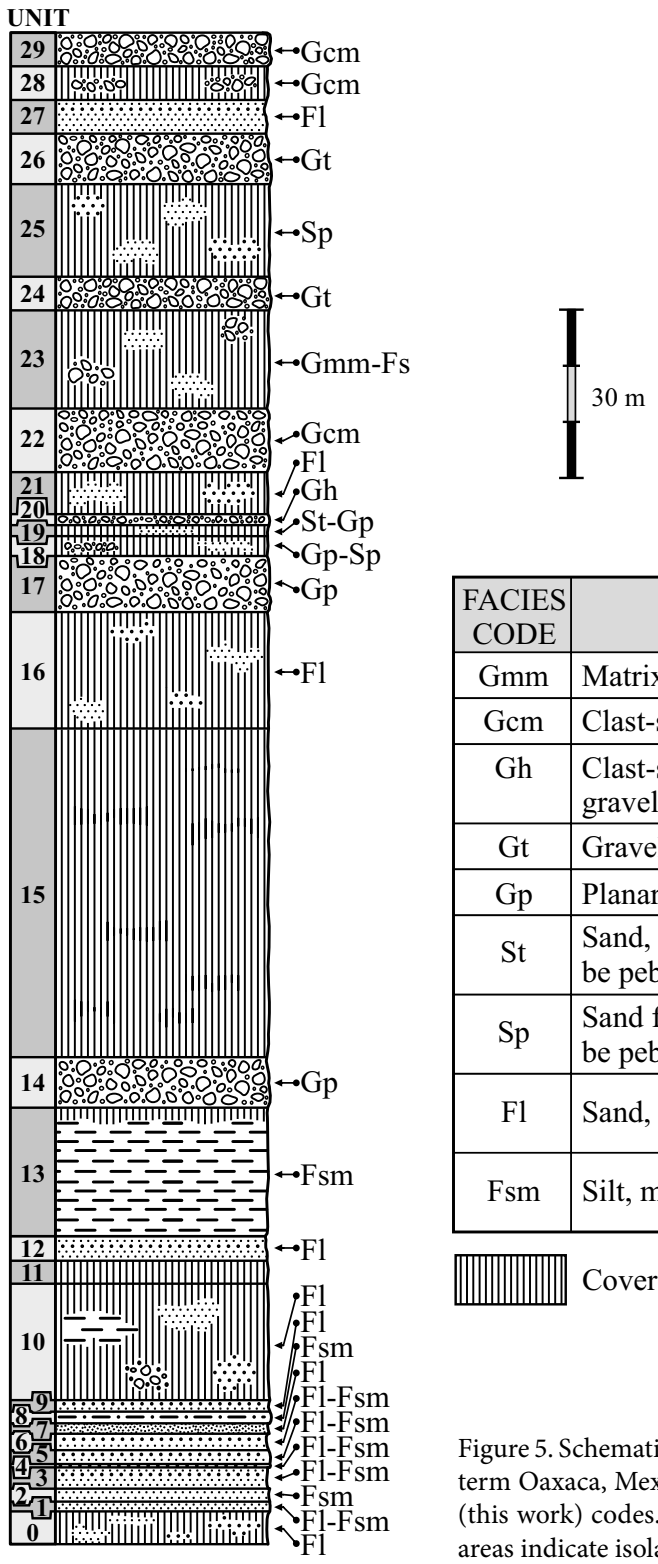

\begin{tabular}{|c|l|l|}
\hline $\begin{array}{c}\text { FACIES } \\
\text { CODE }\end{array}$ & \multicolumn{1}{|c|}{ FACIES } & \multicolumn{1}{|c|}{$\begin{array}{c}\text { SEDIMENTARY } \\
\text { STRUCTURES }\end{array}$} \\
\hline Gmm & Matrix-suppoted, massive gravel & Weak grading \\
\hline Gcm & Clast-supported massive gravel & - \\
\hline Gh & $\begin{array}{l}\text { Clast-supported, crudely bedded } \\
\text { gravel }\end{array}$ & $\begin{array}{l}\text { Horizontal bedding } \\
\text { imbrication }\end{array}$ \\
\hline $\mathrm{Gt}$ & Gravel stratified & Trough cross-beds \\
\hline $\mathrm{Gp}$ & Planar cross-beds & Planar cross-beds \\
\hline $\mathrm{St}$ & $\begin{array}{l}\text { Sand, fine to very coarse, may } \\
\text { be pebbly }\end{array}$ & $\begin{array}{l}\text { Individual or grouped } \\
\text { trough cross-beds }\end{array}$ \\
\hline $\mathrm{Sp}$ & $\begin{array}{l}\text { Sand fine to very coarse may } \\
\text { be pebbly }\end{array}$ & $\begin{array}{l}\text { Individual or grouped } \\
\text { planar cross-beds }\end{array}$ \\
\hline $\mathrm{Fl}$ & Sand, silt mud & $\begin{array}{l}\text { Laminated sandstone, } \\
\text { siltstone and mudstone }\end{array}$ \\
\hline Fsm & Silt, mud & $\begin{array}{l}\text { Masive siltstone and } \\
\text { mudstone }\end{array}$ \\
\hline
\end{tabular}

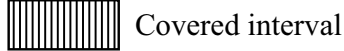

Figure 5. Schematic representation of the Yolomécatl Formation principal reference section, northwesterm Oaxaca, Mexico, slightly modified to include the fluvial (Miall, 2006) and lacustrine lithofacies (this work) codes. The latter was generated following Miall's (2006) criteria. The small, punctuated areas indicate isolated outcrops within the given interval.

\section{RESULTS AND DISCUSSION: DEPOSITIONAL SYSTEMS OF THE YOLOMÉCATL FORMATION, A FIRST APPROACH}

\section{Initial remarks}

Ferrusquía-Villafranca et al. (2016b) showed that the Yolomécatl Formation records lake, and fluvial sedimentation, as well as intermittent felsic pyroclastic deposits preserved in a small, triangle-shaped tectonic basin bound by the Teposcolula fault in the north, the Ticú fault in the east, and the río Mixteco-río Negro fault in the west and south (Figure 2). The contrasting lithology on both sides of these faults is an evidence of their presence. Additionally, the Teposcolula fault plane is visible in the Yolomécatl-Nicananduta road, some $1.6 \mathrm{~km}$ west of Yolomécatl, as well as in La Presita area, where the dip of Yolomécatl strata is high. It should be noted that these three faults are synsedimentary, but the Ticú fault was more active, thus the sedimentary fill is thicker in the east.

This tectonic basin lies close to the regional, N-S trending, leftlateral, strike-slip Tamazulapam fault, and thus, very probably could be genetically related to the dynamics of this fault. It is noteworthy that the east-ward continuation of the Teposcolula and río Mixteco-río Negro faults place them in contact with the Tamazulapam fault (Figure 6), thus defining a larger graben (so far unnamed), where the Yolomécatl tectonic basin is just one of three major blocks. This rather complex structural array associated to the dynamics of a major strike-slip fault (Tamazulapam), is scale aside, also similar to that reported by Crowell (2003a, 2003b) for the Ridge Basin, and Harding et al. (1985, p. 68, fig. 19, particularly in the bottom part) for the Andaman Sea, northwestern Pacific Ocean, which are areas of concentrated transtensional/ transpressional stress along curved zones of major strike-slip faults. Due to the objectives of this paper, the structure of blocks A and C need no further description.

Structurally, the best part of the Yolomécatl Formation shows a moderate, largely east-southeastward dipping (10-15 $)$; however, in the southern portion, the dips are usually higher (up to $27^{\circ}$ ), and strike north and northeast; this anomalous dipping is related to the presence of NW-SE striking faults (of normal and lateral type, Figure 6). The 
Table 1. Description of the Yolomécatl Formation Stratotype, northwestern Oaxaca, Mexico. Source: Ferrusquía-Villafranca et al., $2016 \mathrm{~b}$, table B.2.

\begin{tabular}{|c|c|c|}
\hline Unit & Description & Thickness (m) \\
\hline & $\begin{array}{l}\text { Hill summit located at } 17^{\circ} 26^{\prime} 56.4^{\prime \prime} \mathrm{N} \text { Lat. and } 97^{\circ} 34^{\prime} 26.8^{\prime \prime} \mathrm{W} \text { Long.; end of measured section. The formation continues further east, but } \\
\text { its ruggedness onward makes it unpractical to continue measuring. }\end{array}$ & \\
\hline & Total measured & $73.11 \mathrm{~m}$ \\
\hline 25 & Red siltstone. Upper part is full of rootlets. & 1.00 \\
\hline 24 & Friable, weekly cemented, red siltstone set in thick strata. & 9.00 \\
\hline 23 & Pebble, clast-supported volcarenitic, conglomerate. & 0.02 \\
\hline 22 & Red siltstone set in massive strata; the base of the unit is a $0.2 \mathrm{~m}$-thick strata of pebble, clast supported volcarenitic conglomerate. & 6.20 \\
\hline 21 & Partly silicified, felsic vitric tuff sheets set in mediumly thick strata; silica "lakes" have partly destroyed the vitroclastic structure. & 0.60 \\
\hline 20 & Red, moderately fossiliferous, friable siltstone and fine-grained sandstone set in massive strata. & 1.59 \\
\hline 19 & Light gray, vitric, partly welded, rhyolitic ash fall tuff. & 0.26 \\
\hline 18 & Slightly silty claystone set in thick strata; vague lamination is hardly discernible. & 8.70 \\
\hline 17 & Light gray, felsic, vitric ash fall tuff. & 0.20 \\
\hline 16 & Red clay and silt set in mediumly thick to thick strata. & 1.43 \\
\hline 15 & Light gray, felsic, vitric ash fall tuff. & 0.32 \\
\hline 14. & Red clay and silt set in thick strata; a vague lamination is barely discernible. & 2.36 \\
\hline 13 & Light gray, felsic, vitric-crystal tuff sheets; it forms a thick stratum. & 0.45 \\
\hline 12 & Red, friable claystone set in thick strata; a vague lamination is barely discernible. & 1.05 \\
\hline 11 & Red, moderatly lithified claystone forming a thick bed. & 0.50 \\
\hline 10 & Red, friable claystone and siltstone set in mediumly thick to thick strata; a vague lamination is discernible. & 3.00 \\
\hline 9 & Red, well indurated claystone set in thick strata. & 1.00 \\
\hline 8 & Red, friable fine-grained sandstone and siltstone set in thick strata. & 4.50 \\
\hline 7 & $\begin{array}{l}\text { Very hard, dark gray and whitish zoned/banded, vitric-lustered silica; typically the bands/zones are delimitated by plane to convoluted } \\
\text { surfaces or show ameboid/digit-shaped projections that intrude the adjacent beds. (It seems that the "silica beds" passed through a gel } \\
\text { state before solidifying). Thin sections show an amorphous (glass-like) structure/texture. The rock is set in medium thick strata. }\end{array}$ & 0.05 \\
\hline 6 & Red siltstone and claystone set in thick strata, a vague lamination is barely discernible. & 7.50 \\
\hline 5 & $\begin{array}{l}\text { Light gray, dark gray/light gray banded silica similar to that of unit 1, set in medium strata, overlain by medium thick, gravel-pebble, clast } \\
\text { supported, volcarenitic conglomerate. }\end{array}$ & 0.65 \\
\hline 4. & Red, friable siltstone and claystone set in thick to massive strata; a vague lamination/thin bedding structure is discernible. & 5.70 \\
\hline 3 & $\begin{array}{l}\text { Partly covered interval. A few "windows," show the presence of red claystone and siltstone strata, which in the lower part are peneplained, } \\
\text { becoming badlands upward. }\end{array}$ & 10.50 \\
\hline 2 & Partly covered interval. Windows show strata of red claystone and sandstone. The Rancho Ara road lies in this interval. & 6.00 \\
\hline 1 & $\begin{array}{l}\text { Very hard, brittle (conchoidal fracturing), gray silica set in quasi-regularly alternating light and dark "beds" of variable thickness [5-15 } \\
\text { mm are common]. Fresh surfaces show opaline luster. Typically the "beds" are bound by plane or convolute surfaces, or show ameboid or } \\
\text { finger-like projections that intrude adjacent "beds." (This suggests that the material went through a gel-state before becoming fully solid). } \\
\text { Thin sections show an amorphous (glass-like) structure. The rock forms a fairly thick stratum. }\end{array}$ & 0.53 \\
\hline
\end{tabular}

presence of fibrous gypsum-fillings in sigmoid tensional fractures arranged in echelon, evidences transpression (Figure 7). Alternatively, it could be possible that the río Mixteco-río Negro fault had another (younger) pulse of activity, so that the anomalous dip values reflect dragging near the fault plane. Actually, both hypotheses complement each other, producing a more plausible solution to the anomalous dipping mentioned above.

The rocks that make up the Yolomécatl Formation are distributed in three geographic zones or belts that show a broad concentric pattern (Figure 8) around a N-S elongate, irregularly shaped, relatively large core, located in the east, which consists of deeply intertongued conglomerate (more abundant) and fine-grained stratal stacks, as well as tuff sheets (relatively scarce); the core is fairly rugged and set at higher altitude than that of the surrounding belts; its margins include fine-grained sediments. The inner belt consists of clay, silt and fine-grained sandstone set in thin to thick strata, showing vaguely horizontal laminations (i.e. laminar to very thin beds) that form a red, thick sequence that laps around the coarse-grained core, defining a distinctive geomorphology consisting of a semicircular outcrop area, expressed as a zone of badlands; several conglomeratic and pyroclastic strata are intercalated in the sequence; vertebrate fossils were recovered from this zone. The outer belt includes an irregular succession of tuff sheets (more abundant) and fine-grained strata; this fact indicates that volcanic eruptions were frequent but not continuous, and that during the eruption-free lapses, fine clastic sedimentation took place, thus producing interbedding of tuff and sedimentary strata. The outcrops extend northwestwards, finally meeting the volcanic Nicananduta Group.

\section{Fluvial system}

The fluvial system largely forms the core mentioned above (Figure 8), where several kinds of deposits are found. Such deposits include the following ones:

\section{Gmm, Gmg, Gcm Lithofacies: Alluvial fans and related deposits}

These deposits partly include the $\mathrm{CH}$ architectural element (Figure 9); they are mainly located in the core, and consist of clast- or matrixsupported gravel (sensu lato) deposits, which usually show massive bedding, or less commonly, subtle thick bedding. The interstices 
Table 2. Description of the Yolomécatl Formation Principal Reference Section, northwestern Oaxaca, Mexico. Source: Ferrusquía-Villafranca et al., $2016 \mathrm{~b}$, table B.3.

\begin{tabular}{|c|c|c|}
\hline Unit & Description & Thickness (m) \\
\hline 29 & $\begin{array}{l}\text { Largely cobble, andesitic, clast-supported volcarenitic conglomerate set in thick to massive strata; tabular cross-bedding is vaguely } \\
\text { discernible; slight clast imbrications toward NE is discernible. }\end{array}$ & 6.00 \\
\hline 28. & Partly covered interval. Windows show a volcarenitic, clast-supported conglomerate set in thick to massive strata. & 6.00 \\
\hline 27 & Red siltstone set in thin to laminar strata, which form massive stratal packages. & 6.00 \\
\hline 24 & $\begin{array}{l}\text { Pinkish, well indurated, clast-supported, cobble, andesitic volcarenitic conglomerate set in thick strata. Tabular cross-bedding is vaguely } \\
\text { discernible. }\end{array}$ & 6.00 \\
\hline \multirow[t]{2}{*}{23} & $\begin{array}{l}\text { Covered interval. The site is a plain with numerous, andesitic gravel to cobble clasts on the surface; occasionally red siltstone shows up. } \\
\text { (Likely, an alternate sequence of conglomerate and siltstone underlies the plain). }\end{array}$ & 17.49 \\
\hline & Detour to the west, $123 \mathrm{~m}$. & \\
\hline 18 & $\begin{array}{l}\text { Partly covered interval. Windows show conglomerate, as well as red siltstone and fine-grained sandstone strata. (This interval is } \\
\text { interpreted as a rhythmic/alternate sequence of conglomerate and fine clastics strata). }\end{array}$ & 3.54 \\
\hline 17 & $\begin{array}{l}\text { Red, gravelly cobble, andesitic, well indurated, clast-supported, volcarenitic, tabular cross-bedded conglomerate set in thick to massive } \\
\text { strata. }\end{array}$ & $10 \mathrm{e}$ \\
\hline 16 & Covered interval, upper part (a plow field). (The absence of large clasts suggests that fine grained sediments underlie the field). & 20.75 \\
\hline 15 & $\begin{array}{l}\text { Covered interval lower part (a plow field). At the top, make a } 71 \mathrm{~m} \text { westward detour to pick a } \mathrm{N} 12^{\circ} \mathrm{E} \text { trending path to continue measuring. } \\
\text { (This implied a slight change in to the due } \mathrm{N} \text { strike of section). }\end{array}$ & 50.58 \\
\hline 14 & Pinkish gray, well consolidated, gravelly cobble, andesitic, tabular cross-bedded, volcarenitic conglomerate set in thick to massive strata. & 9.00 \\
\hline 13 & Red, friable claystone set in thin to laminar beds that form massive packages. The uppermost part $(\sim 0.20 \mathrm{~m})$ is covered. & 22.90 \\
\hline 12 & Red, friable siltstone and fine-grained sandstone set in thin to mediumly thick strata. & 4.38 \\
\hline 6 & Red siltstone and fine-grained sandstone without discernible bedding. & 2.92 \\
\hline 5 & Red, friable siltstone and fine-grained sandstone set in this to laminar beds that form massive strata. & 2.48 \\
\hline 4 & Red and fine-grained sandstone set in mediumly thick strata. & 0.59 \\
\hline 3 & Red siltstone and fine-grained sandstone set in thin to mediumly thick strata. & 3.80 \\
\hline 2 & Red, friable siltstone set in thin strata. & 2.33 \\
\hline 1 & $\begin{array}{l}\text { Red siltstone and fine-grained sandstone set in very thin to laminar beds that form massive strata. The beds dip } 17^{\circ} \text { to N57 }{ }^{\circ} \text {. [Such dip } \\
\text { is assumed for this formation along the section]. }\end{array}$ & 1.75 \\
\hline 0 & $\begin{array}{l}\text { Partly covered interval. The absence of coarse-grained suggests the presence of siltstone/fine-grained sandstone [common material of } \\
\text { this lithostratigraphic unit]. }\end{array}$ & 5.84 \\
\hline
\end{tabular}

between larger clasts are filled with unsorted sandstone, siltstone and clay; a few tuff sheets were observed on the Yolomécatl-Ticú road (Figure 2). The irregular shape of the core strongly suggests that its outgoing projections may correspond to alluvial fan lobes, which in turn disclose some lateral accretion; one of such lobes is partly traversed by the Yolomécatl-Ticú road. Along this road, there are some structureless, matrix-supported gravel deposits that could be of debris flow type.

\section{Gm, Gh, Gp, Gt, St, Sp Lithofacies: Channel lag deposits}

These deposits include the $\mathrm{CH}$ architectural elements (Figure 10), and are made up of clast-supported conglomerate (largely pebble to cobble clasts) set in medium to thick (and even massive) strata; the small ones are typically lensoid, with concave bottoms, interpreted as subsidiary channels, others form blankets a few centimeters thick and probably record avulsion episodes. Typically, these small forms seem to be absent in the core, but are present in the inner belt at various 


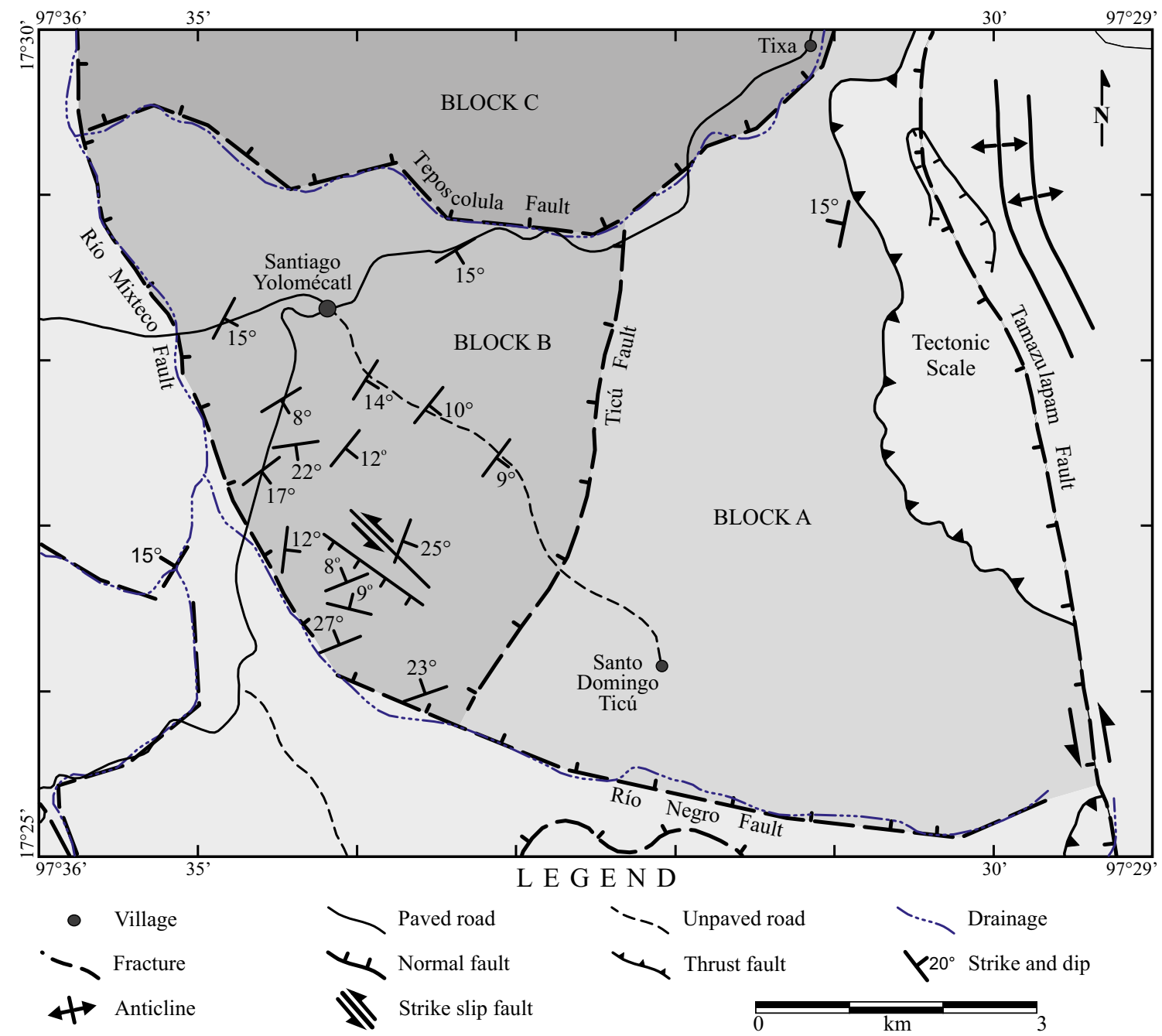

Figure 6. Structural setting of the Yolomécatl tectonic basin, Block (B) with the adjacent Eastern (A) and Northern (C) Blocks, as well as their spatial relationship with the Tamazulapam Fault. The main structural features of the Yolomécatl Formation are also depicted.

stratigraphic levels; such belt, as mentioned above, largely records clastic lake deposition. The presence of conglomerate deposits in this belt, indicates that the lake bottom was intermittently subaerially exposed, and partly traversed by small channels; if so, the St lithofacies would also be present. The larger deposits could correspond to major channels, bars of diverse types, or subterminal fan facies, however the paucity of outcrops prevented making out their precise shapes. Only in one outcrop, 'La Cascadita' (Figures 2 and 11), sited on the west, there is a conglomerate body intercalated with tuff sheets and fine-grained epiclastic strata; its geographic position suggests that the conglomerate source area was located to the west, where the Nduayaco Group also crops out.

\section{Sr, Sl, Sh, Fl Lithofacies: Floodplain deposits}

These deposits include the FF architectural element and partly make up the inner belt (Figure 12). The presence of fine gravel sensu stricto and sandstone rock bodies in the area is rare, a fact unexpected in fluvial deposits; none occurs in the 'core,' whereas a few were observed in the inner belt, whose constitution (medium to fine-grained sandstone or siltstone) makes them difficult to tell them apart from the true, fine-grained clastic lake deposist that largely form the inner belt. The main criterion to tell them apart is the occurrence of low angle laminar/tabular cross-bedding in the floodplain deposits, which contrasts with the vaguely thin to laminar bedding of the lake deposits. Further, this kind of deposits (floodplain) largely consist of friable to slightly indurated silty claystone, clayey siltstone and fine-grained sandstone that form tabular bodies usually $<1.0 \mathrm{~m}$ thick.

The presence of structureless zones in the fine-grained sequence, largely formed by dark clays allows us to interpret them as paleosols (Figure 13) developed in exposed flood plain deposits (and/or in lake bottoms). Paleosols were observed at least in three sites, El Llano, Rancho Ara, and CECYT (a high school). In the latter, Calamospora (a soil fungus) and Salvinia (an aquatic fern) are abundant (in different stratigraphic levels), which indicates that the site/area was aerially exposed and soil could develope, which later became flooded, so that the aquatic fern could thrive. Variable lake levels could foster a similar effect.

This fine-grained, friable sequence formed badlands, thus showing resemblance to those cropping out in the Dakota Badlands (Retallack, 1983). Fungal and plant palynomorphs recovered from these zones, bolster this interpretation, as does the finding of terrestrial mammals, which also disclose the availability there of lands not covered by water. Further, the palynomorphs recovered include an admixture of tropical and temperate plant taxa (in Table S1 of the Supplementary Material). 
Figure 7. Picture showing the presence of fibrous gypsum-fillings in sigmoid tensional fractures (indicated by the opposing arrows). By contrast, in the upper part a fibrous gypsum pseudobed fills a nearly horizontal fracture.

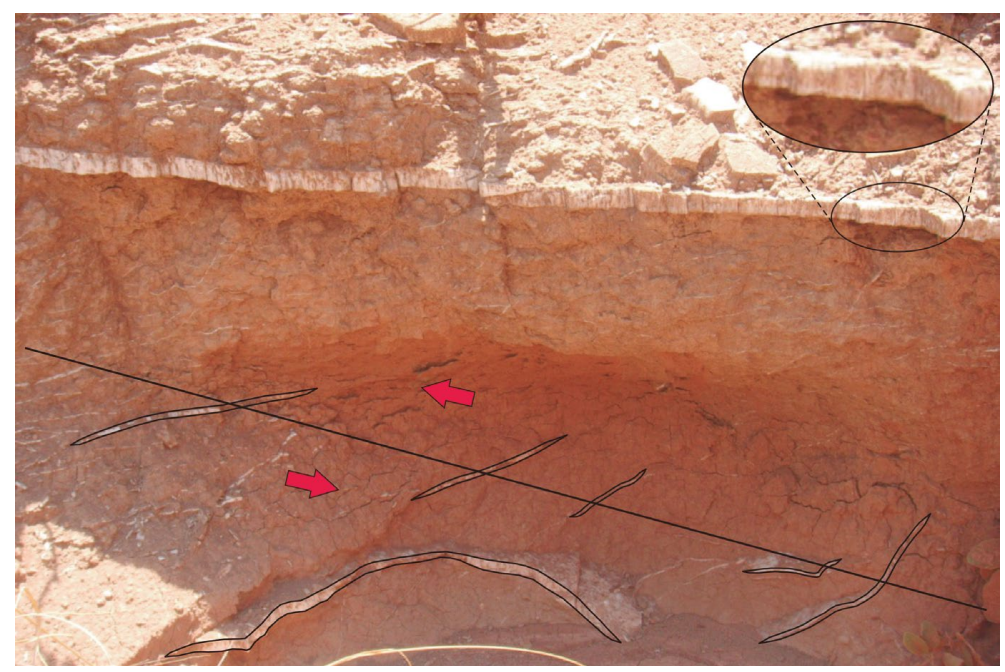

This assemblage may shed light on the origins of the Cordilleran Flora (Axelrod and Raven, 1985), and on the development of montane forests (Wijnga, 1995).

\section{Lacustrine system}

The inner 'belt' (Figure 8) is a conspicuous red, badlands zone (devoided of a vegetation cover), formed by a clastic sequence at least $650 \mathrm{~m}$ thick (although in the principal reference section, the nearly continuously exposed thickness is only $250 \mathrm{~m}$ ); it is mainly constituted by fine-grained sediments set in thin to thick strata or stratal packages vaguely showing laminar to very thin beds devoided of cross-stratification, thus indicating clastic deposition in (shallow) lakes. Local interbedding of thin conglomerate layers and/or lenses (already described above) indicates subaerial exposure of the lake bottom. The sequence also includes tuff sheets ( $>0.60 \mathrm{~m}$ thick) which are more resistant to erosion than the adjacent fine-grained beds, thus forming within this sequence ridges at an early stage of erosion, or outstanding cuestas delimited by cliffs, where the overlying friable, fine-grained beds have been eroded away, and the underlying strata could not recede beyond the cuesta exposed limit.

\section{Ll, Lm, Lsm: Lacustrine clastic (offshore) facies}

This facies (Figure 14) consists of fairly abundant smectite claystone (determined by X-Ray difractometry, Ferrusquía-Villafranca et al., 2016b), clayey siltstone and fine-grained, subarkosic (quartz-rich) sandstone with a minor phyllarenitic composition, where the quartz grains have sharp edges, and most show undulatory extinction, a distinct feature of metamorphic origin. The feldspar grains (8-10\%) are weathered (cloudy appearance) and less angular than those of quartz; there is an abundant clayey and slightly calcite-cemented matrix. The source-area of fine-grained sediments probably involved the Nduayaco Group, thus accounting for the volcanic (feldspar) component, whereas that of the metamorphic component (i.e. the undulatory extinction quartz grains) probably includes the undifferentiated, middle Jurassic Zorrillo/Taberna formations, or directly the late Paleozoic Acatlán Complex, which are the nearest geologic units that bear undulatoryextinction quartz crystals.

The fine-grained clastics are set in thin to laminar beds forming strata up to $\sim 3$ meters thick, where a vague lamination is observed; this condition does not allow to detect varves, or to recognize cycles. The large thickness of the inner belt $(\sim 650 \mathrm{~m})$ indicates either a very deep lake basin or a shallow one that subsided pari passu with sedimentation.
The presence of thin channel lag and floodplain deposits in this largely fine-grained sequence, favors the second alternative.

\section{Ll, Lsm: Lacustrine shore and mudflat deposits}

Theoretically, this kind of deposits could be present, however a deep intertonguing that occurs between the conglomerate and fine-grained beds/facies (Figure 15) indicates that the lake shore (probably narrow) was very dynamic (and so was the lake level), repeatedly advancing inland or receding toward the lake, thus largely covering the lake shore deposits; however, we found three sites where fine-grained sandstone and siltstone (mudstone) vaguely set in thin to medium strata crop out, and bearing numerous reed plant remains, indicative of this kind of deposits (Talbot and Allen, 1996). Additionally, the presence of these marginal/lake shore vegetation taxa: Typha sp., Saggitaria sp. and Cyperus sp. (see the Supplementary Material), strongly support this interpretation. The scarcity of suitable outcrops prevented us from detecting and describing other such deposits.

\section{Environmental significance of the palynoflora}

The palynoflora recovered from the Yolomécatl Formation/ sequence (see the Supplementary Material) consists of a moderately diverse array of lacustrine, marginal and terrestrial, largely tropical taxa: among the first are green algae like Zygnemataceae, the Tetrasporina Group, and abundant spores of the floating fern Salvinia; marginal (shore) aquatic plants include Typha, Saggittaria, Cyperus and Cupressaceae (cypresses); terrestrial plants comprise the arboreal taxa Acacia, Mimosa, Bombax, Anacardiaceae (mango family), Moraceae (fig family) and Arecaceae (palm family), known to have a tropical distribution since the Cretaceous. This flora indicates that the bearing geologic unit was deposited in diverse places: lake, lake shore and terrestrial (fluvial) sedimentary environments, under tropical climatic conditions, thus providing additional support to the environmental discrimination described above.

\section{Pryroclastic sheets and associated lake deposits}

Pyroclastic sheets, although do not conform a depositional system per se, are considered here, because they did contribute to generate the Yolomécatl Formation, aided to date it and to understand its depositional history. Such sheets largely occur in the outer belt (Figure 8), together with lacustrine strata similar to those of the inner belt (i.e. red claystone, siltstone and fine-grained sandstone strata), which tend to be thicker than the sheets. 

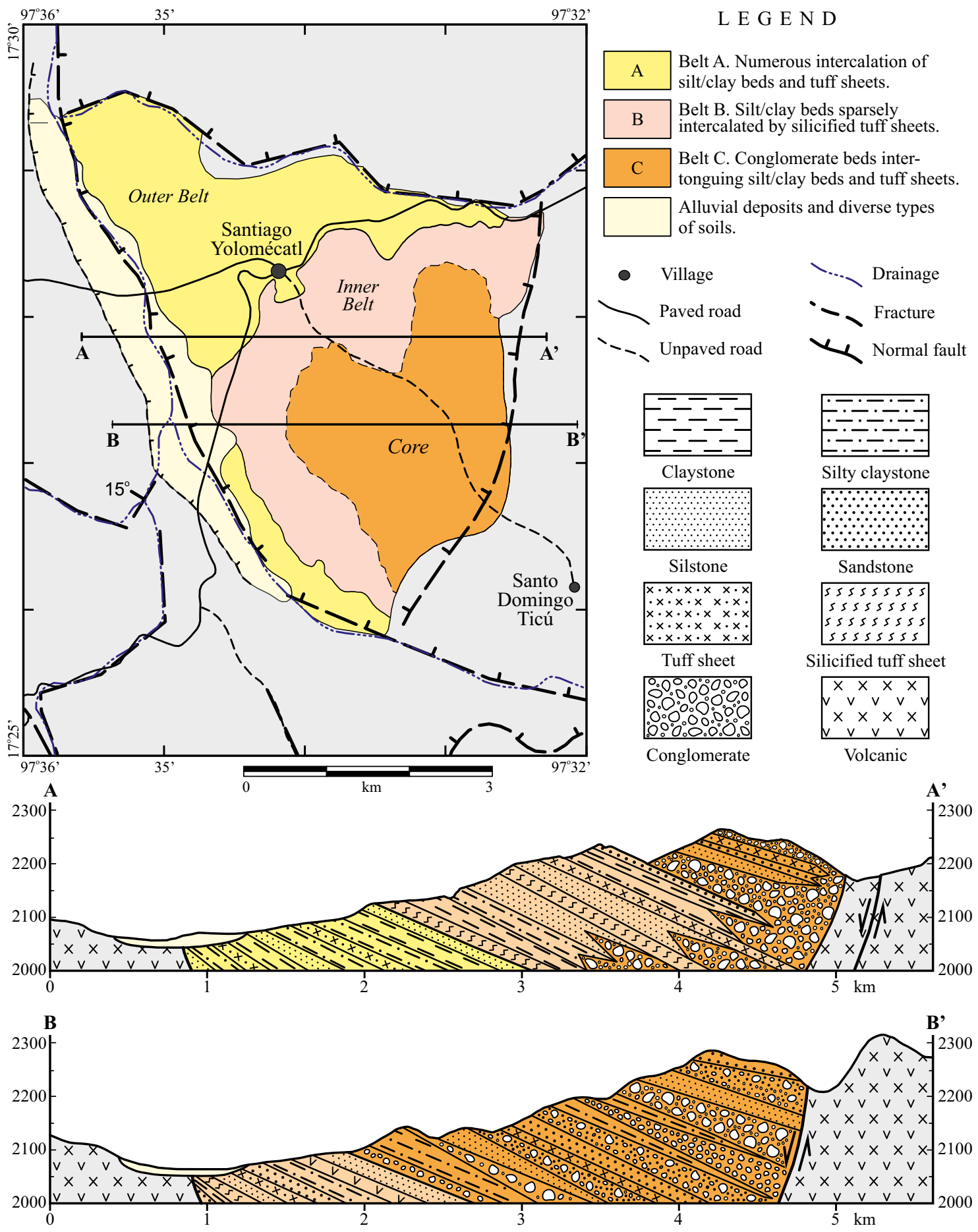

Figure 8. Schematic space distribution of the depositional belts of the Yolomécatl Formation. Notice that the vertical dimension, in the sections, is exaggerated three times to better show sedimentary features.

\section{Pyroclastic sheets}

The ash flow tuff sheets (Figure 16) are usually light ochre (varying from whitish to light brown), and consist of glass shards and pumice. They exhibit a variable degree of welding (from unwelded, partly welded to fully welded); some show cross-bedding and dune structures, both are diagnostic of pyroclastic flow emplacement (Branney y Kokelaar, 2002; Sulpizio et al., 2014). Some sheets are strongly altered by silicification (chertification). It should be noted that the tuff sheets show no evidence of previous movilization or reworking, thus indicating that they are primary deposits. However, given that tuffs of low grade welding erode rapidly, we might expect somewhere deposits formed by this process.

Both, tuffs sheets and epiclastic beds are set in strata of variable thicknesses, i.e. from laminar to thin to medium or thick strata. The superior toughnees/hardness of the tuffs makes them to stand out from the lacustrine beds, forming cliff-bound cuestas where the fri- 

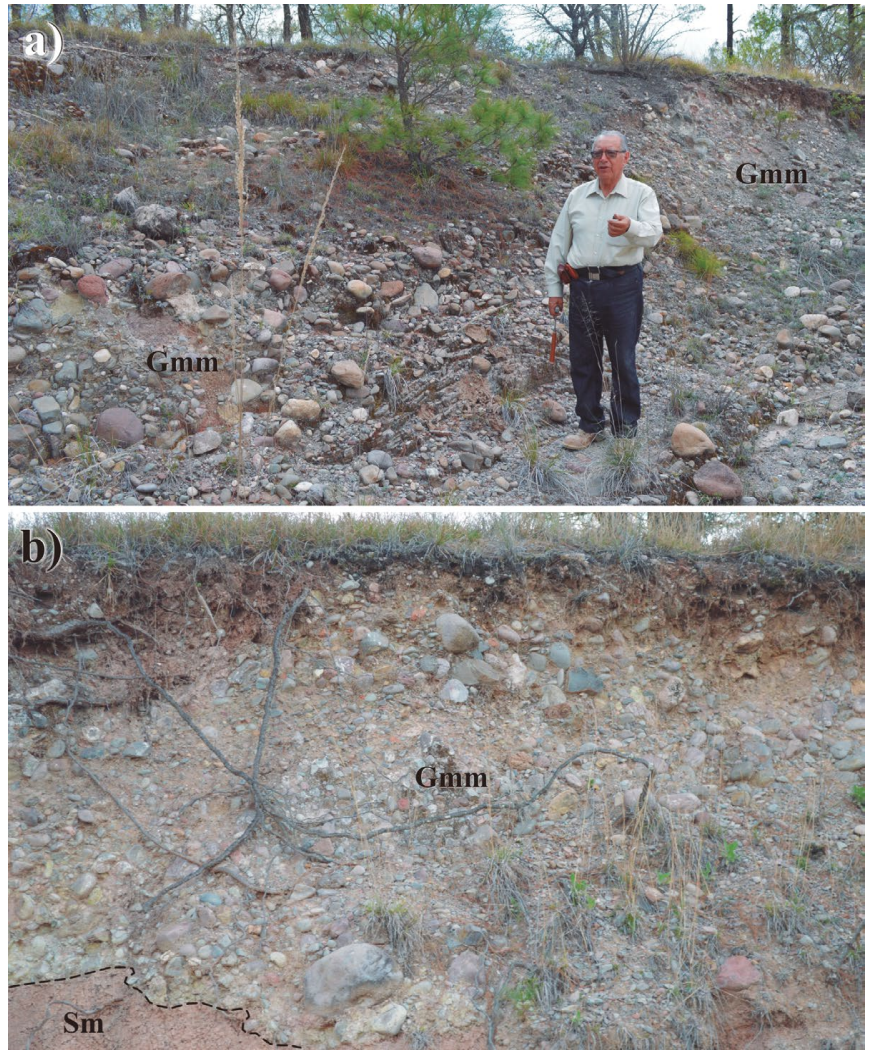

Figure 9. Fluvial system of the Yolomécatl Formation: Alluvial fans and related deposits. a) Shows part of a terminal alluvial fan lobe conglomerate strata. b) Shows an outcrop of a debris flow deposit. Notice the lack of stratification.

able overlaying beds have been eroded away, and the underlying ones could not recede beyond the tuff sheet edge. In the outer belt, tuff sheets seem to be volumetrically more abundant than the epiclastic deposits. The alternation of tuff sheets and fine strata indicates that volcanic eruptions were frequent, but not continuous, and that during the eruption-free lapses, fine clastic sedimentation continued, until interrupted by another pyroclastic emplacement. This belt's crop out area extends about $3 \mathrm{~km}$ northwest of Yolomécatl, until contacting the Nicananduta Group. This fact suggests that the source-area of the tuffs sheets probably laid northwest of the Yolomécatl Basin.

\section{Concluding remarks on the depositional systems of the Yolomécatl Formation}

It is quite possible that the Yolomécatl basin, as well as its sedimentary fill, experienced instability because it lies close to the regional, left-lateral strike-slip Tamazulapam fault, and its bounding faults (Teposcolula in the north, río Mixteco/río Negro in the west and south, and the Ticú in the east). It is likely that this tectonic activity might have caused variable lake levels and mobile lake shores.

Furthermore, the presence of paleosols at different stratigraphic levels indicates that floodplains and/or lake shores and even lake bottom deposits became episodically exposed to subaerial conditions, which induced development of soils (now they are paleosols), and of a vegetation cover, thus providing food and shelter to vertebrates that lived there.

The dynamics of the lake shore advancing toward the land or receding toward the lake accounts for the intertonguing of conglomerate and fine-grained strata (Figure 16). Perhaps another factor was the forma-
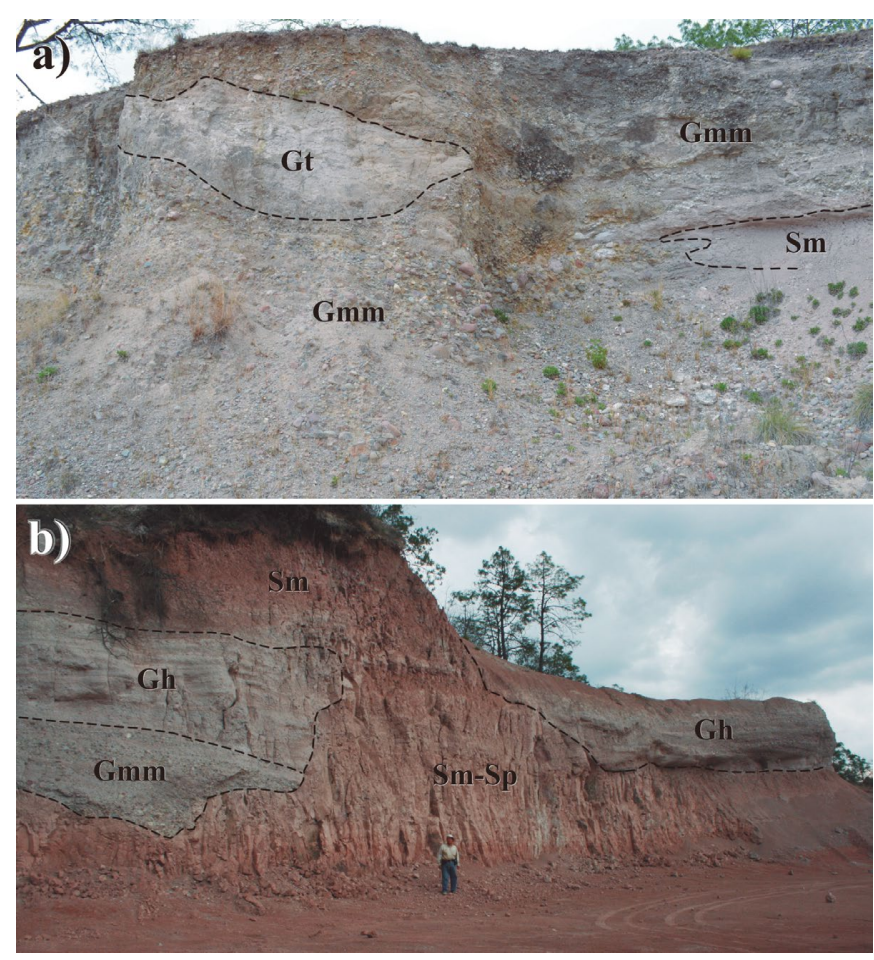

Figure 10. Fluvial System of the Yolomécatl Formation: Channel lag deposits. a) and b) show conglomerate lenses formed by channel lag conglomerate deposits filling scours on fine-grained lacustrine strata.

tion of piedmont deposits by gravity sliding of clasts on steep slopes. The lake or lakes received the suspended load from incoming rivers, which laid down in laminar to very thin beds formed by fine-grained sediments, and also received dust from the atmosphere. The pyroclastics indicate synsedimentary volcanism from a source probably located northwest of the Yolomécatl tectonic basin; the dominant small size of these pyroclastics may indicate that the volcano that produced them was not close to this basin. On the other hand, the mechanism of pyroclastic sheets chertification is not well understood; however, the presence of convolute confining surfaces in strata of chertified tuff, discloses the existence of a plastic, gel-like phase during the process of chertification.

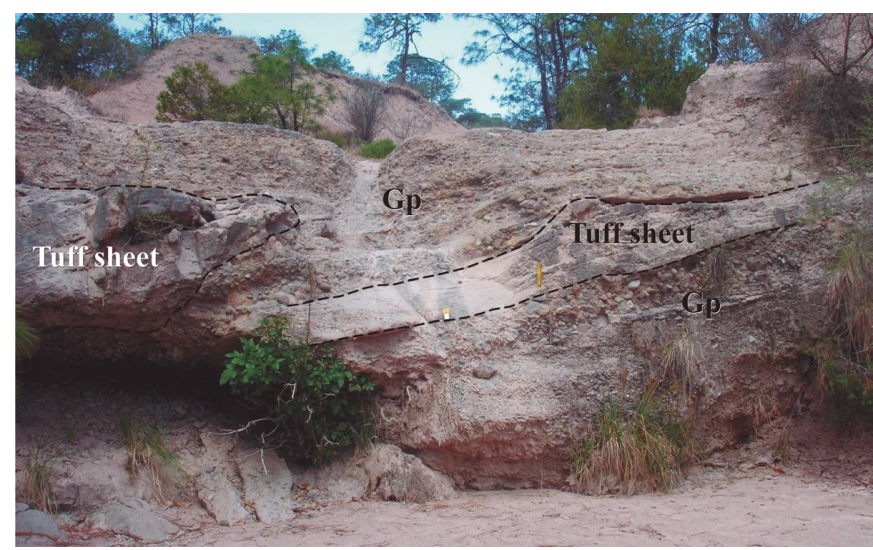

Figure 11. La Cascadita outcrop. It shows tuff sheets (featureless zones) interbedded with conglomerate strata $(\mathrm{Gp})$ of different clast size; the upper ones are finer-grained than the lower ones. 


\section{TECTONO-SEDIMENTARY EVOLUTION OF THE YOLOMÉCATL BASIN AND OF ITS SEDIMENTARY FILL: A FIRST APPROACH}

It should be noted that the Yolomécatl tectonic basin developed in a tectonically active zone, which influenced its genesis and sedimentary filling (see below, paragraph on thickness of the Yolomécatl Formation). The influence of the regional, left-lateral, strike-slip Tamazulapam fault, particularly of its transtensive activity, generated the basin. Usually, this kind of basins subside rapidly, and if the sedimentary input is large, thick sedimentary deposits are formed.

After the emplacement of the Nduayaco Group, the left-lateral, strike-slip Tamazulapam fault became active again, inducing transtension, normal faulting, and the genesis/development of the Yolomécatl tectonic basin, which occurred prior to $\sim 40.3 \mathrm{Ma}$, age yielded by a ${ }^{40} \mathrm{Ar}-{ }^{39} \mathrm{Ar}$ analysis of a tuff sheet interbedded in the fine-grained sequence of the Yolomécatl Formation (Ferrusquía-Villafranca et al., 2016b). This basin is small ( $40 \mathrm{~km}^{2}$, at least $650 \mathrm{~m}$ total depth), triangle-shaped, and bound by three faults: Teposcolula in the north, Ticú in the east, and río Mixteco-río Negro in the west and south (Ferrusquía-Villafranca et al., 2016b).

Given that the Yolomécatl Formation strata chiefly dip to the east-southeast (Figures 2, 6 and 8), it follows that: a) the exposed western strata are older than the eastern ones; b) The eastern Ticú fault was more active than the others, which is expected, given its greater proximity to the Tamazulapam fault; c) The eastern part of this formation is thicker $(\sim 650 \mathrm{~m})$ than the western. However, the continuous exposure that served as principal reference section, measures only $250 \mathrm{~m}$; d) The geographic distribution of the depositional systems is such that, the coarsest facies (intertonguing of conglomerate with the fine-grained sediments) lie in the east, the fine-grained beds in the center, and the fine- grained strata-tuff sheets succession lies in the west; e) At any given stratigraphic level, the three components of this formation are coetaneous, and $\mathrm{f}$ ) Based on the geographic distribution and physical characteristics of the sediments, the source-area laid in the east.

The great thickness of the Yolomécatl Formation ( $\sim 650 \mathrm{~m}$ at least) indicates that the containing basin could have been deep or shallow. If the Yolomécatl tectonic basin was originally deep, it follows: a) Absence of cross-bedded strata in the Yolomécatl sequence. b) Presence of dark, anoxic strata rich in organic matter. c) Presence of turbidites; both b) and c) occur, at least, in the lower part of the sequence. However, the Yolomécatl Formation does not display these attributes. On the other hand, if the basin was originally shallow, the great thickness of this

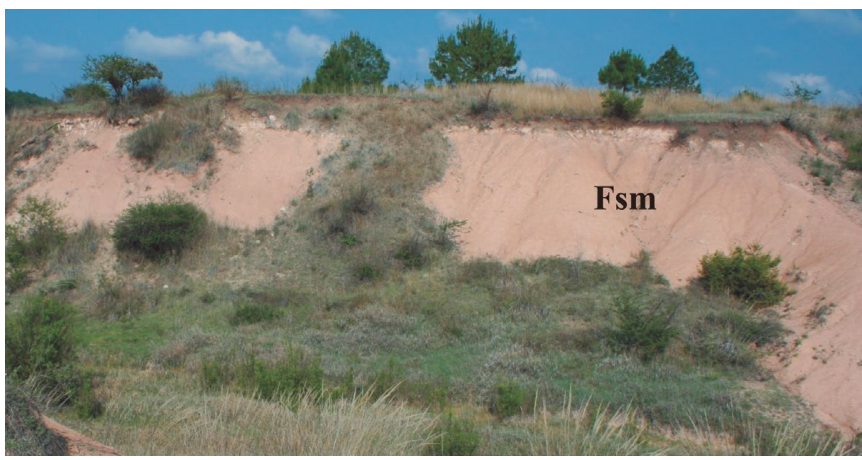

Figure 12. Fluvial System of the Yolomécatl Formation: Floodplain deposits. Notice that loose conglomerate fall and vegetation interrupt the continuity of the floodplain exposure.
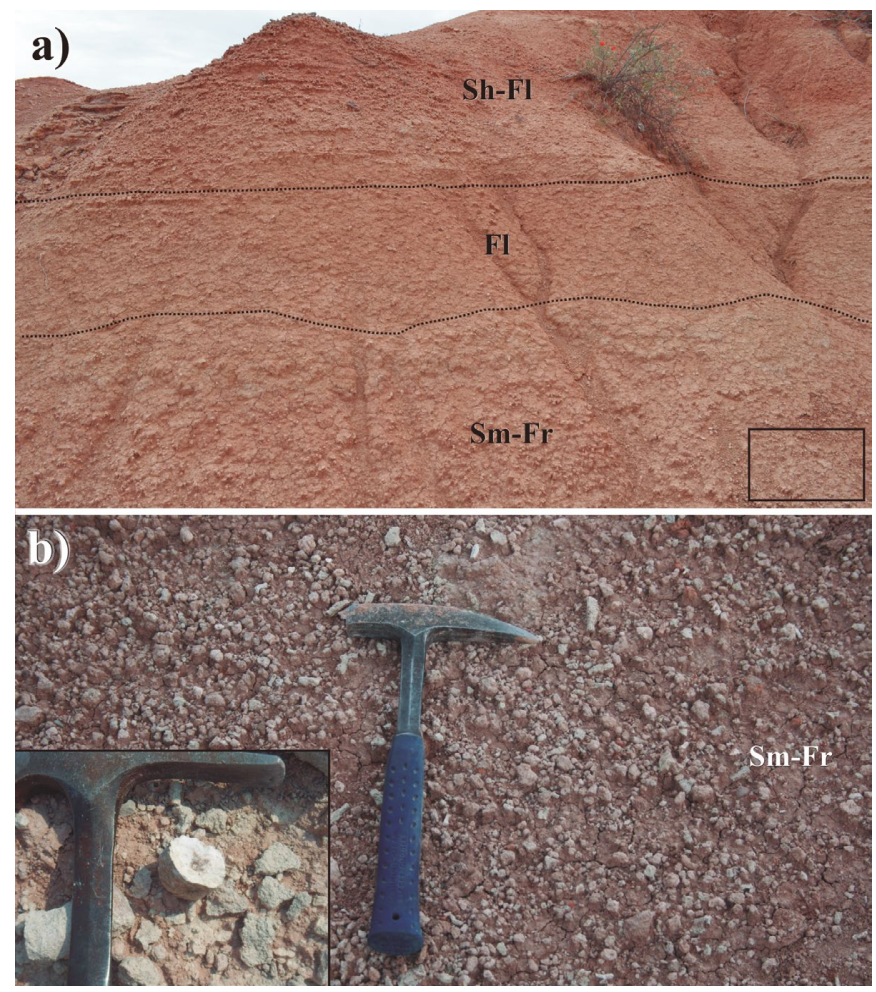

Figure 13. Paleosols. a) Paleosols developed in an exposed lake bottom. b) Close up of the lower right inset square in a), which shows numerous rootlets. The bottom left square in b) depicts one rootlet.
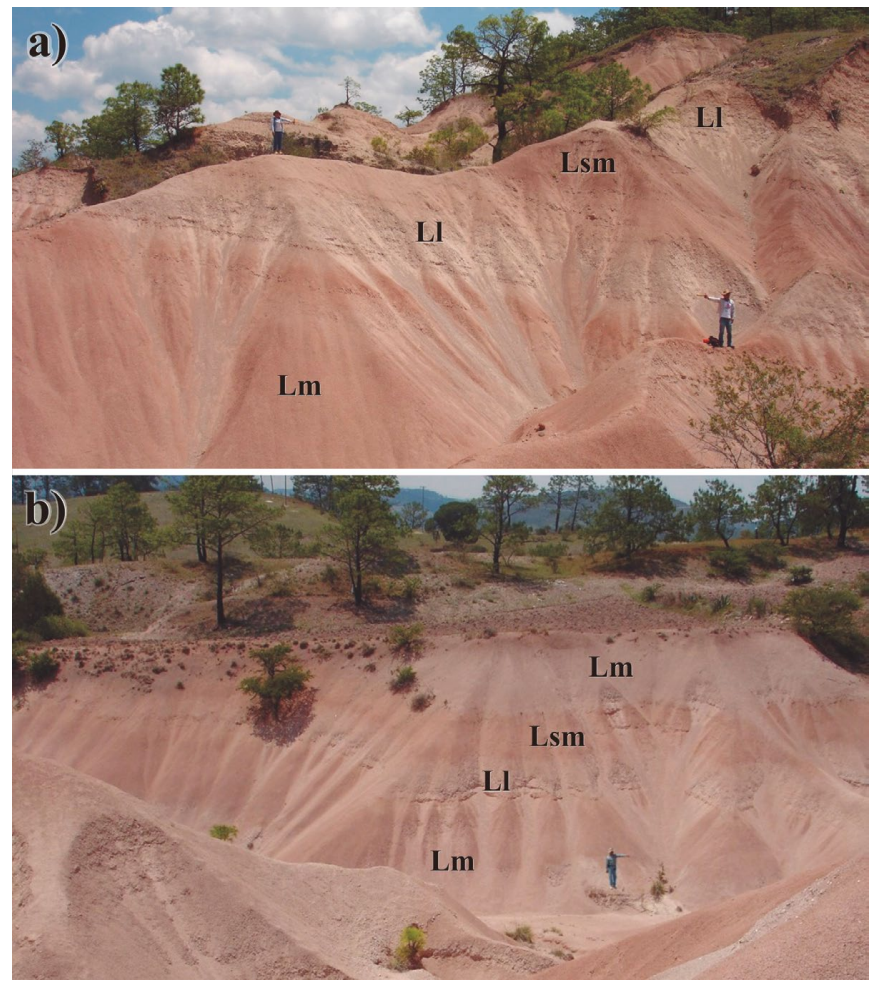

Figure 14. Lacustrine clastic offshore facies. a) and b) depict fine-grained sequences. 
unit could be explained by synsedimentary tectonic subsiding pari passu with deposition. Further, the following facts observed in the Yolomécatl Formation add plausibility to this hypothesis: a) Presence of cross-bedded strata at several levels of the (lake) sequence (indicating intermittent subaerial exposure of the lake bottom, followed by the establishment of fluvial deposition). b) Presence of paleosols at several levels of the sequence. Both sets of features of the Yolomécatl Formation provide reliable criteria supporting the shallow basin hypothesis.

The latter process may account for the composition and structure observed in Yolomécatl strata, whereby the coarser, conglomerate strata largely lie on the east (i.e. close to the Nduayaco Group mountains, their purported source area), the fine-grained sediments in the center, which are sparsely intercalated by tuff sheets, and the fine-grained strata and tuff sheet intercalations chiefly lie in the west (see Figure 17).

It should be noted that the horizontal emplacement of the tuff sheets, may be used as an indicator of basin floor tilting (reflected by the strata tilting/dipping) due to faulting, examples: in the northwest, where the older Yolomécatl strata are exposed, the measured dip is $15^{\circ}$ SE, i.e. similar to those measured in the Yolomécatl-Ticú road, whereas in those of the southwest, close to the río Mixteco-río Negro fault, the dip values are greater (up to $27^{\circ}$ ), thus disclosing a younger episode of faulting. Further evidence of such faulting is the presence in the southern part of two small faults (normal and lateral respectively), and of fine-grained strata showing a diversity of dip strikes and values. On the other hand, the general southeastward strata dipping suggests that the Ticú structure is a growth fault, and that it was more active than the Teposcolula and río Mixteco-río Negro faults, also of growth type, thus affording greater accommodation space for the sediments.

The succession of fine-grained strata and tuff sheets, although somewhat irregular, discloses the time coincidence of felsic volcanism and fine-grained sediment deposition. Such succession also indicates that volcanism was episodic rather than continuous. The limited accommodating space afforded by this small basin, suggests that deposition could largely occur vertically, stacking subsequent threecomponent tabular bodies, one over the other; however, some down stream lateral accretion took place. In short, vertical accretion prevailed over lateral accretion (Figure 17), as in the Ridge and Tolentino basins (Crowell, 2003a, 2003b, and Ferrusquía-Villafranca et al., 2016a respectively). Finally, Figure 17 shows an environmental reconstruction of the area, some time during the late Eocene.

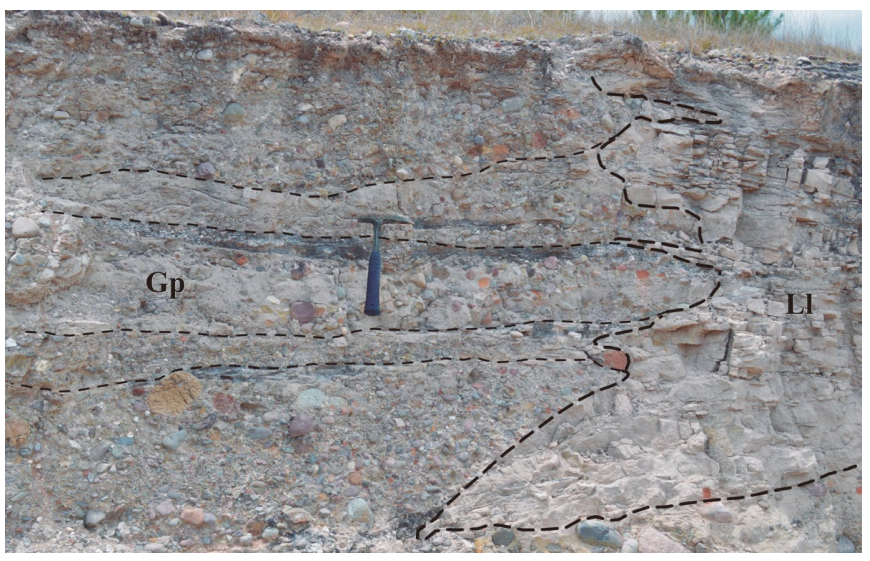

Figure 15. Intertonguing of coarse (conglomerate) and fine-grained (lake shore) strata that illustrates advance and retreat of the lake shore.
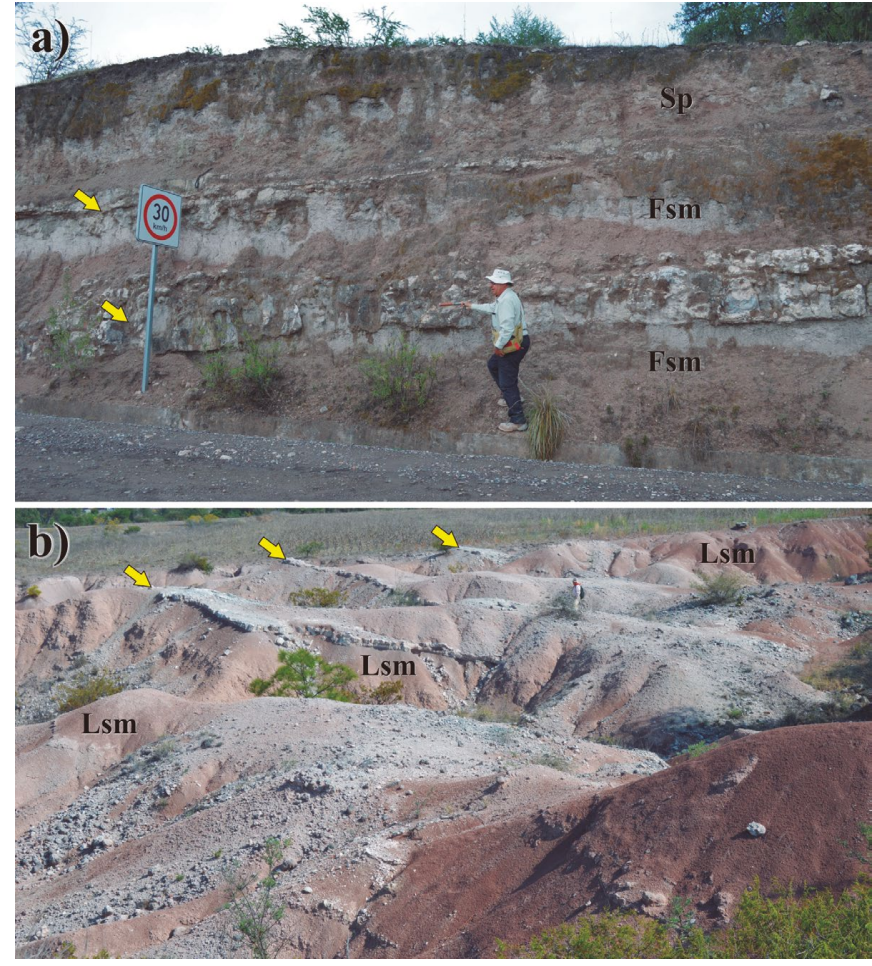

Figure 16. Pyroclastic System: Pyroclastic sheets (exposed as ridges or cuestas) a) Shows tuff sheets (marked by yellow arrows) intercalated in an offshore lake sequence. b) Depicts the badlands geomorphology, here dominated by small cuestas bound by cliffs developed in places where the friable beds overlying tuff sheets (marked by yellow arrows) have been largely eroded away, and the underlying ones could not recede beyond the tuff sheets margins.

\section{SUMMARY AND CONCLUSIONS}

The geologic study of the Yolomécatl Formation, lead us to the following conclusions:

1. The early late Eocene, epiclastic Yolomécatl Formation largely fills the namesake triangle-shaped tectonic basin, which is bound by three faults: Teposcolula (in the north), Ticú (in the east) and río Mixteco-río Negro (in the west and south); such basin developed in a territory influenced by the regional, left-lateral, strike-slip Tamazulapam fault. The large thickness $(\sim 650 \mathrm{~m})$ of Yolomécatl Formation in relation to its surface extent $\left(\sim 40 \mathrm{~km}^{2}\right)$, indicates that vertical accretion prevailed over lateral accretion, in response to the limited accommodating space provided by this tectonic basin, and to the synsedimentary activity of the bounding faults.

2. The Yolomécatl Formation records lacustrine and fluvial deposition, as well as synsedimentary volcanic activity that emplaced several tuff sheets (a pyroclastic system on its own) at various levels in the lake and fluvial sequences, which either intertongue or alternate among themselves. The fluvial system includes these facies and deposits: Gmm, Gmg, Gcm lithofacies: Alluvial fans and related deposits; Gm, Gh, Gp, Gt, St, Sp lithofacies: Channel lag deposits; and Sr, Sl, Sh, Fl lithofacies: Floodplain deposits. The lacustrine system largely includes these facies and deposits: Ll, Lm, Lsm lithofacies: offshore deposits; and: Ll, Lsm: lacustrine shore and mud flat deposits. The pyroclastic system consists of tuff sheets sparsely interbedded/intercalated in the other two systems. The palynoflora recovered from the Yolomécatl Formation lends additional support to this environmental interpretation. 
YOLOMECATL TECTONIC BASIN

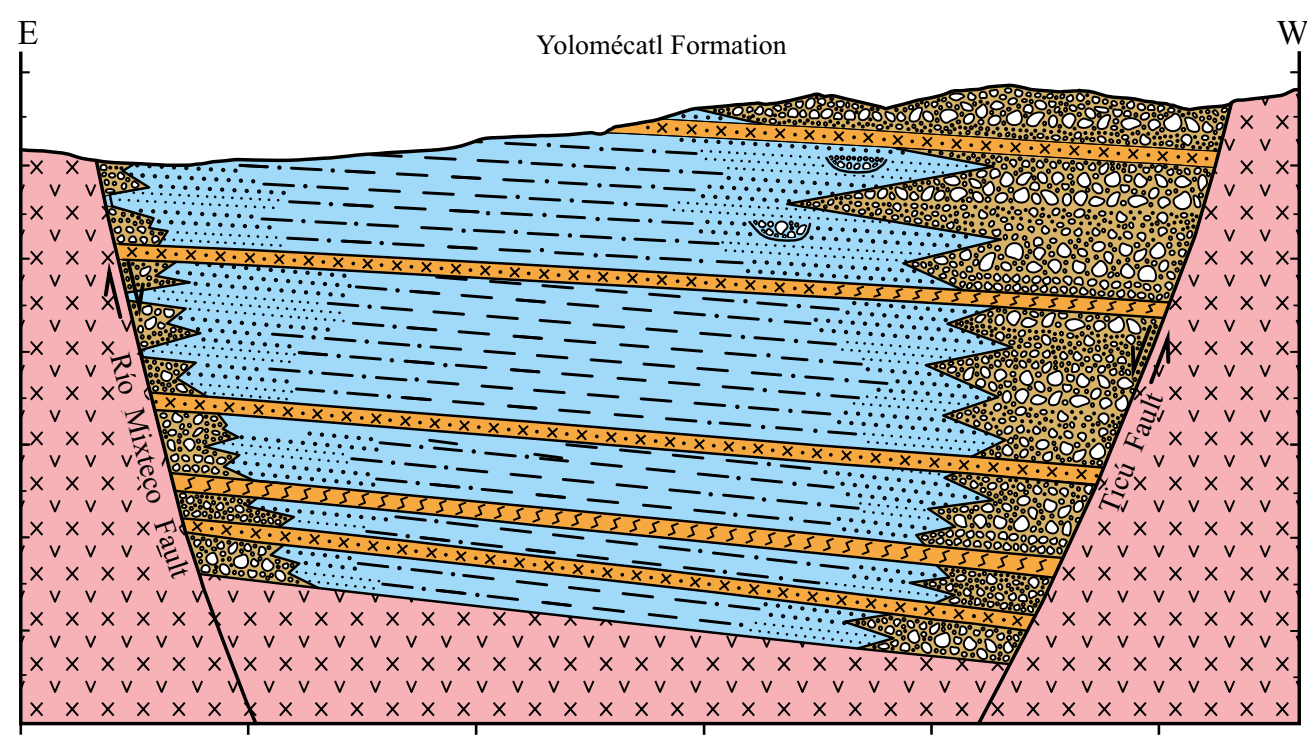

L E G E N D

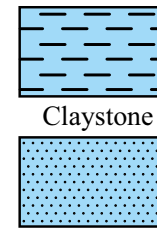

Silstone

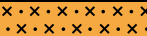

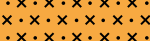

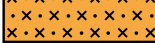

Tuff sheet

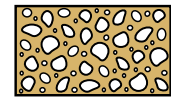

Conglomerate

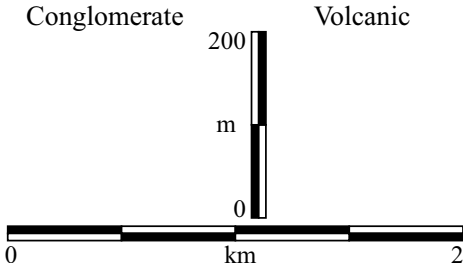

Figure 17. Schematic reconstruction of the depositional systems of the Yolomécatl Formation some time during the late Eocene. Notice that this formation fills the namesake tectonic basin. The coarse conglomeratic deposits (largely alluvial fans) lie adjacent to fault planes, the eastern ones are greater and better developed than the western ones; both intertongue fine-grained lacustrine strata, and are sparsely interbedded by tuff sheets.

3. Areally, such systems have a peculiar space distribution, so that in the east lies a north-south elongate, lobated rock body, the core, largely formed by volcarenitic conglomerate set in thick to massive strata (fluvial system), deeply intertongues with red, fine-grained strata (chiefly lacustrine system), similar to those laminar to thin bedded ones that form the inner belt that surrounds the core. Finally, there is an outer belt surrounding the inner one, that consists of tuff sheets (pyroclastic system), irregularly, interbedded, fine-grained strata similar to those of the inner belt; the outer belt also shows a narrow northwest projection partly capped by the Nicananduta Group. It should be noted that the red, friable, readily erodable, sparsely vertebrate-fossiliferous sediments that form the inner belt, also define a conspicuous zone of badlands.

4. The Yolomécatl Formation strata chiefly dip east-southeastward, so that the unit is thicker in the east than in the west; the strata exposed in the west are relatively older than those cropping out in the east. The sedimentary architecture of this basin's fill, discloses that the Ticú fault (in the east) was more active than the others, and behaved as a growing fault.

\section{ACKNOWLEDGEMENTS}

Institutions. The present work stems from the project Estudio geológico-geofísico, tectono-sedimentario, biótico y paleoambiental del Terciario continental de la Cuenca Yolomécatl-Tlaxiaco, Oaxaca Occidental: Implicaciones en el entendimiento de la evolución Cenozoica del Sureste, which was kindly financed by the Dirección General de Asuntos del Personal Académico de la Universidad Nacional Autónoma de México (UNAM) through grant PAPIIT-IN 110614, to whom we duly thank. The authors also thank the authorities of the Instituto de Geología, UNAM, and the Instituto de Geología of the Universidad Autónoma de San Luis Potosí (UASLP) for their support and encouragement to develop this project. The municipal authorities of Santiago Yolomécatl graciously permitted us to work in their land.
Individuals. We also cordially thank doctors Tim Lawton, Jorge Aranda and an anonymous reviewer for their thorough job, which permitted us to improve the paper. Last but not least, the authors duly thank the Project-Scholarship Students Guillermo Manuel García Hernández, Cintia Nayely Hernández Ramos, Karla Patricia Ortega Sales, Elizabeth Gómez López, Zanni Hernández Pérez, Gabriela Franco Torres, Brian Giovanni Martínez Bautista, Nancy Grabriela Camacho López, Jakelín Alejandra Fuentes Ortíz, and Miriam Alvear Peralta for their help in all aspects of the project, including field work.

\section{REFERENCES}

Axelrod, D.I., Raven, P.H., 1985, Origins of the Cordilleran Flora: Journal of Biogeography, 12, 21-47.

Batten, J.D., 1999, Small palynomorphs, in Jones, T.P., Rowe, N.P. (eds.), Fossil plants and spores: Modern techniques: Geological Society of London, Miscellaneous Titles, 396, 15-19.

Boggs, S., Jr., 2003, Petrology of sedimentary rocks: Caldwell, New Jersey, The Blackburn Press, 707 pp.

Branney, M.J., Kokelaar, P., 2002, Pyroclastic Density Currents and the Sedimentation of Ignimbrites: Geological Society Memoir, 27, $143 \mathrm{pp}$.

Chávez-Cabello, G., Aranda-Gómez, J.J., Molina-Garza, R.S., Cossío-Torres, T., Arvizu-Gutiérrez, I.R., González-Naranjo, C.A., 2007, The San Marcos Fault: Jurassic multi-reactivated basement structure in northeastern México, in Alaniz-Álvarez, S.A., Nieto-Samaniego, A.F. (eds.), Geology of Mexico: Celebrating the Centenary of the Geological Society of Mexico: Geological Society of America Special Paper, 422, 261-286.

Collinson, J.D., 1996, Alluvial sediments, in Reading, H.G. (ed.), Sedimentary Environments: Processes, Facies and Stratigraphy: Oxford, Blackwell Publishing Company, 37-82.

Crowell, J.C., 2003a, Introduction to geology of Ridge Basin, Southern California, in Crowell, J.C. (ed.), Evolution of Ridge Basin, southern California: An interplay of sedimentation and tectonics: Geological Society of America Special Paper, 367, 1-15.

Crowell, J.C., 2003b, Tectonics of Ridge Basin region, Southern California, in Crowell, J.C. (ed.), Evolution of Ridge Basin, southern California: An 
interplay of sedimentation and tectonics: Geological Society of America Special Paper, 367, 157-203.

Ferrusquía-Villafranca, I., 1976, Estudios geológico-paleontológicos en la Región Mixteca, Parte 1. Geología del Ãrea Tamazulapam-TeposcolulaYanhuitlán, Mixteca Alta, Estado de Oaxaca: Universidad Nacional Autónoma de México, Boletín del Instituto de Geología, 97, 160 pp.

Ferrusquía-Villafranca, I., 1996 (1997), Contribución al Conocimiento Geológico de Chiapas: El Area Ixtapa-Soyaló: Universidad Nacional Autónoma de México, Boletín del Instituto de Geología, 110, 130 pp.

Ferrusquía-Villafranca, I., Ruiz-González, J.E., 2011, Modelo evolutivo tectonosedimentario del Graben Valle de Oaxaca: Integración parsimoniosa de la información geológica y paleontológica disponible, Libro de Resúmenes, Dr. Zoltan de Cserna: Sesenta años geologizando México: Universidad Nacional Autónoma de México, Instituto de Geología, Publicación Especial (en CD), 165-171.

Ferrusquía-Villafranca, I., Ruiz-González, J.E., Torres-Hernández, J.R., Martínez-Hernández, E., Gama-Castro, J., 2016a, A new Miocene formation from The Peotillos-Tolentino Graben fill, western Sierra Madre Oriental at San Luis Potosí, México: Part 2, Depositional environments and regional significance: Boletín de la Sociedad Geológica Mexicana, 68(2), 283-304.

Ferrusquía-Villafranca, I., Ruiz-González, J.E., Torres-Hernández, J.R., Anderson, T.H., Urrutia-Fucugauchi, J., Martínez-Hernández, E., GarcíaVillegas, F., 2016b, Cenozoic geology of the Yolomécatl-Tlaxiaco Area, Northwestern Oaxaca, Southeastern México: Stratigraphy, structure and regional significance: Journal of South American Earth Sciences, $72,191-226$

Fisher, R.V., Schmincke, H.U., 1984, Pyroclastic Rocks: Berlin, Springer-Verlag, 472 pp.

Folk, R.L., 1974, Petrology of sedimentary rocks: Austin, Texas, Hemphill, $184 \mathrm{pp}$.

Haenggi, W.T., 2002, Tectonic history of the Chihuahua Trough, Mexico and adjacent USA, Part II: Mesozoic and Cenozoic: Boletín de la Sociedad Geológica Mexicana, LV(1), 38-94.

Harding, T.P., Vierbuchen, R.C., Christie-Blick, N., 1985, Structural Styles, PlateTectonic Settings, and Hydrocarbon Traps of Divergent (Transtensional) Wrench Faults, in Biddle, K.T., Christie-Blick, N. (eds.), Strike-Slip Deformation, Basin Formation, and Sedimentation: The Society of Economic Paleontologists and Mineralogists (SEPM) and Society for Sedimentary Geology, 51-77.

INEGI (Instituto Nacional de Estadística Geografía e Informática), 1984, Carta Topográfica Yolomécatl E14D35, escala 1:50000: México D.F., Instituto Nacional de Estadística Geografía e Informática, 1 mapa.

Ingram, R.L., 1954, Terminology for the thickness of stratification and parting units in sedimentary rocks: Geological Society of America Bulletin, 65, 937-938.

Jiménez-Hidalgo, E., Smith, K.T., Guerrero-Arenas, R., Alvarado-Ortega, J., 2015, The first Late Eocene continental assemblage from tropical North America: Journal of South America Earth Sciences, 57, 39-48.
Mandujano-Velázquez, J.J., Keppie, J.D., 2009, Middle Miocene Chiapas fold and thrust belt of Mexico: a result of collision of the Tehuantepec Transform/ Ridge with the Middle America Trench: London, Geological Society, Special Publications, 327, 55-69.

Miall, A.D., 2006, The geology of fluvial deposits. Sedimentary Facies, Basin Analysis, and Petroleum Geology: Berlin, Springer-Verlag, 582 pp.

Miall, A.D., 2010, The geology of stratigraphic sequences: Berlin, SpringerVerlag, $522 \mathrm{pp}$.

NACSN (North American Commission on Stratigraphic Nomenclature), 2005, North American Stratigraphic Code, Revised Edition: American Association of Petroleum Geologists Bulletin, 89(11), 1547-1591.

Puy-Alquiza, M.J., Miranda-Aviles, R., García-Barragán, J.C., Loza-Aguirre, I., Li, Y., Zanor, G.A., 2017, Facies analysis architecture and depositional environments of the Guanajuato Conglomerate in the Sierra de Guanajuato, México: Boletín de la Sociedad Geológica Mexicana, 69(29), 385-408.

Retallack, G.J., 1983, Late Eocene and Oligocene paleosols from Badlands National Park, South Dakota: Geological Society of America, Special Paper, 193, $82 \mathrm{pp}$

Schmid, R., 1981, Descriptive nomenclature and classification of pyroclastic deposits and fragments: Recommendations of the International Union of Geological Sciences Subcommission on the Systematics of Igneous Rocks: Geology, 9, 41-43.

Sulpizio, R., Dellino, P., Doronzo, D.M., Sarocchi, D., 2014, Pyroclastic density currents: State of the art and perspectives: Journal of Volcanology and Geothermal Research, 283, 36-65.

Talbot, M.R., Allen, P.A., 1996, Lakes, in Reading, H.G. (ed.), Sedimentary Environments-Processes, Facies and Stratigraphy: Oxford, Blackwell Publishing, 83-124.

Tha, H.V., Wysocka, A., Pha, P.D., Cuong, N.Q., Ziółkowski, P., 2015, Lithofacies and depositional enviroments of the Paleogene/Neogene sediments in the Hoanh Bo Basin (Quang Ninh province, NE Vietnam): Geology, Geophysics \& Enviroment, 41(4), 353-369.

Wijnga, V.M., 1995, A first approximation of montane forest development during the Late Tertiary in Colombia, in Churchill, S.P., Balslev, H., Forero, E., and Luteyn, J. (eds.), Biodiversity and conservation of neotropopical montane forests: Proceedings of the Neotropical Montane Forest Biodiversity and Conservation Symposium, The New York Botanical Garden, 23-34.

Manuscript received: november 16, 2017

Corrected manuscript received: march 14, 2018

Manuscript accepted: march 24, 2018 